\title{
Adaptability and transferability of flood loss functions in residential areas
}

\author{
H. Cammerer ${ }^{1}$, A. H. Thieken ${ }^{2}$, and J. Lammel ${ }^{3, *}$ \\ ${ }^{1}$ Institute of Geography, University of Innsbruck, Innrain 52f, 6020 Innsbruck, Austria \\ ${ }^{2}$ Institute of Earth and Environmental Science, University of Potsdam, Karl-Liebknecht-Str. 24-25, 14476 Potsdam, Germany \\ 3 alpS GmbH, Grabenweg 68, 6020 Innsbruck, Austria \\ *now at: TIWAG-Tiroler Wasserkraft AG, Eduard-Wallnöfer-Platz 2, 6020 Innsbruck, Austria
}

Correspondence to: H. Cammerer (holger.cammerer@uibk.ac.at)

Received: 11 July 2013 - Published in Nat. Hazards Earth Syst. Sci. Discuss.: 25 July 2013

Revised: 21 October 2013 - Accepted: 31 October 2013 - Published: 29 November 2013

\begin{abstract}
Flood loss modeling is an important component within flood risk assessments. Traditionally, stage-damage functions are used for the estimation of direct monetary damage to buildings. Although it is known that such functions are governed by large uncertainties, they are commonly applied - even in different geographical regions - without further validation, mainly due to the lack of real damage data. Until now, little research has been done to investigate the applicability and transferability of such damage models to other regions. In this study, the last severe flood event in the Austrian Lech Valley in 2005 was simulated to test the performance of various damage functions from different geographical regions in Central Europe for the residential sector. In addition to common stage-damage curves, new functions were derived from empirical flood loss data collected in the aftermath of recent flood events in neighboring Germany. Furthermore, a multi-parameter flood loss model for the residential sector was adapted to the study area and also evaluated with official damage data. The analysis reveals that flood loss functions derived from related and more similar regions perform considerably better than those from more heterogeneous data sets of different regions and flood events. While former loss functions estimate the observed damage well, the latter overestimate the reported loss clearly. To illustrate the effect of model choice on the resulting uncertainty of damage estimates, the current flood risk for residential areas was calculated. In the case of extreme events like the $300 \mathrm{yr}$ flood, for example, the range of losses to residential buildings between the highest and the lowest estimates amounts to a factor of 18 , in contrast to properly validated models with a factor of
\end{abstract}

2.3. Even if the risk analysis is only performed for residential areas, our results reveal evidently that a carefree model transfer in other geographical regions might be critical. Therefore, we conclude that loss models should at least be selected or derived from related regions with similar flood and building characteristics, as far as no model validation is possible. To further increase the general reliability of flood loss assessment in the future, more loss data and more comprehensive loss data for model development and validation are needed.

\section{Introduction}

Flood damage assessment has attracted growing attention in recent years as its consideration in frame of flood risk analysis is still new and immature (Büchele et al., 2006; Merz et al., 2010). Besides the interest within the scientific community, the need of flood loss estimations ranges from decisions on loss compensations by disaster funds and financial appraisals of the (re-)insurance sector, to risk maps required by legislation like the Floods Directive 2007/60/EC and evaluation of risk reduction projects (Dutta et al., 2003; Downton and Pielke, 2005; Merz et al., 2010; Jongman et al., 2012; Meyer et al., 2013). The European Floods Directive 2007/60/EC, for instance, requires that all European member states have flood hazard and flood risk maps at the river basin scale in areas of significant flood risk (EC, 2007). Flood risk usually considers the hazard characterized by the probability and intensity of certain flood events and the associated potential consequences (EC, 2007). However, a majority of the 
member states has until recently only few or no flood risk maps that include information on the consequences of potential floods (de Moel et al., 2009).

Flood consequences are generally measured by the exposure of elements at risk and their vulnerability, often expressed in monetary terms (Thywissen, 2006). Mostly, only the hazard side is depicted, i.e., the flood extent or the potential flood depths (de Moel et al., 2009), which reflects the continuous stronger attention of the hazard side in flood risk analysis (Freni et al., 2010; Merz et al., 2010; de Moel et al., 2012). While much effort is done to improve the hazard estimation leading to more accurate and more reliable models, the estimation of flood damage is still crude and affected by large uncertainties (Merz et al., 2004; Egorova et al., 2008; Freni et al., 2010; de Moel and Aerts, 2011; Meyer et al., 2013).

Until now, there is no standard procedure to determine the flood impact (Oliveri and Santoro, 2000; Nicholas et al., 2001; Luino et al., 2009) resulting in a wide range of flood damage models with substantial differences in their underlying approaches (Merz et al., 2010; Papathoma-Köhle et al., 2011; Jongman et al., 2012; Meyer et al., 2013).

Generally, flood damage can be classified in direct and indirect damage (Smith and Ward, 1998; Merz et al., 2010). Direct damage like loss of life or devastation of buildings and infrastructure comprise those which are caused by the direct physical contact of the flood water with economic assets, humans or any other object (Smith and Ward, 1998). Indirect costs like production loss or cost of emergency service, in contrast, occur inside or outside of the inundated area and often with a time lag, but are induced by the direct impact of the flood event (Cochrane, 2004; Meyer et al., 2013). Both types can be further differentiated in tangible and intangible damage (Smith and Ward, 1998). While tangible damage can be easily expressed in monetary terms, the monetarization of intangible damage, such as impacts on the environment or health, requires different valuation methods since they are not traded on a market (Meyer et al., 2013). More recently, also losses due to business interruption, occurring in areas directly affected by the flood as well as costs of risk mitigation are included as a separate sub-category within loss assessments of natural hazards (for a comprehensive overview see Meyer et al., 2013).

However, the quantification of indirect losses by means of Input-Ouput models or Computable General Equilibrium Analysis, for instance, is still problematic (Cochrane, 2004; Meyer et al., 2013). As stated by Meyer et al. (2013) existing models operate only on an aggregated scale and fail to better reflect the interaction between the economic dynamics and the external shocks by natural disasters in a region. Thus, usually only direct tangible losses are estimated as they are easier to quantify (Merz et al., 2010). For direct losses, susceptibility functions are commonly applied, which relate hazard parameter(s) like water depth with the resulting economic damage of a certain object at risk, for example, residential buildings (Merz et al., 2010; Papathoma-Köhle et al., 2011; Meyer et al., 2013). These susceptibility functions vary nevertheless, when different economic sectors like residential properties, commercial units or agriculture are taken into account. But even by attributing elements at risk to the same economic sector with comparable susceptibility characteristics, flood damage data still contain a large variability (e.g., Merz et al., 2004; Kang et al., 2005; Freni et al., 2010; Pistrika and Jonkman, 2010). As outlined by Thieken et al. (2005) flood damage is controlled by a variety of influencing factors which can generally be differentiated into impact parameters (e.g., water depth, flood duration, flow velocity, contamination) and resistance parameters (e.g., building characteristics including building size and asset value, private precaution, emergency measures).

Although it is known that different processes and characteristics of a flood event govern flood damage (e.g., Kelman and Spence, 2004; Schwarz et al., 2005; Thieken et al., 2005; Merz et al., 2010), the majority of damage estimations apply simple depth-damage functions (Luino et al., 2009; Merz et al., 2010; Meyer et al., 2013) as it is internationally accepted as standard approach for assessing direct urban damage (Smith, 1994). According to Papathoma-Köhle et al. (2011) the usage of stage-damage functions can be dated back to the seminal paper of White (1945), who linked the water level to relative (i.e., the loss ratio) or total (i.e., in monetary values) damage. Since then, flood damage assessment methods were developed in many countries with different complexity and purposes like the "manual of assessment techniques" published by Penning-Rowsell and Chatterton (1977) as the first application in Europe. Currently, most damage models still use inundation depth as the main impact parameter (see e.g., Merz et al., 2010; Jongman et al., 2012 for an overview), but some models also integrate additional parameters like flow velocity (e.g., Schwarz and Maiwald, 2007; Kreibich et al., 2009; Pistrika and Jonkman, 2010), contamination (e.g., Kreibich and Thieken, 2008; Thieken et al., 2008; Prettenthaler et al., 2010), the duration of flooding (e.g., Dutta et al., 2003; Penning-Rowsell et al., 2005) or the recurrence interval (e.g., Elmer et al., 2010). With regard to the consideration of different resistance parameters, the majority of damage models differentiates between the use or type of building (e.g., Oliveri and Santoro, 2000; Dutta et al., 2003; Kang et al., 2005; Büchele et al., 2006; Schwarz and Maiwald, 2007; Kreibich and Thieken, 2008; Thieken et al., 2008). Few models also take additional parameters, such as precautionary behavior (e.g., Büchele et al., 2006; Kreibich and Thieken, 2008; Thieken et al., 2008) or the early warning time (e.g., Penning-Rowsell et al., 2005), into account. Only recently, data mining approaches have been successfully applied to derive more sophisticated damage models (e.g., Merz et al., 2013).

Besides the consideration of one or more damage influencing parameter, flood loss models are either derived empirically from real loss data, such as the models of Thieken et 
al. (2008) and Prettenthaler et al. (2010), or derived synthetically by "what-if-analyses" (e.g., Penning-Rowsell et al., 2005). Another aspect is the division in relative and absolute damage functions. While absolute functions (e.g., PenningRowsell et al., 2005 or Prettenthaler et al., 2010) do not require asset values for the estimation of monetary damage since the asset values are incorporated in the damage function, relative functions (like Schwarz and Maiwald, 2007 or Thieken et al., 2008) express the damage as percentage of the asset value of the respective element at risk. In this case, information on the asset values of the elements at risk is needed in addition. Depending on the purpose of the loss estimation, the cost assessment of asset values can be done by replacement costs (i.e., the estimated new value of the damaged object), which are often used for purposes of (re-)insurers, or by depreciated costs (i.e., the estimated present value of the object at the time when the damage actually occurs), which have to be considered in economic studies or project appraisals (van der Veen and Logtmeijer, 2005; Merz et al., 2010). A comprehensive overview of different flood damage models regarding the differentiation by all these aspects can be found in Merz et al. (2010) and Jongman et al. (2012), for example.

In general, most of the stage-damage curves are assumed to be restricted to floods with low flow velocities where water depth is the dominating factor as a faster flow is expected to increase the probability of higher structural damage due to the dynamic load (Kelman and Spence, 2004; Kreibich et al., 2009; Papathoma-Köhle et al., 2011). BWW et al. (1997) suggest categorizing flooding into a static or dynamic type. While static floods occur predominantly in the lowland with rather low flow velocities and slowly rising water levels, dynamic floods occur often in mountainous regions and are characterized by high velocities and intensive erosion processes (BWW et al., 1997). Since the majority of the stage-damage functions were derived for lowland regions with slowly rising floods, such as for the lower Rhine (MURL, 2000) or the German Lippe catchment (Hydrotec, 2002), their applicability is mainly directed towards static river flooding. In contrast, damage estimation studies that address the dynamical character of flooding by considering flood velocity, for example, are rare (e.g., Schwarz and Maiwald, 2007; Kreibich et al., 2009; Pistrika and Jonkman, 2010). Even if the general consideration of flow velocity in flood damage modeling on buildings cannot be necessarily recommended (Kreibich et al., 2009), the dynamic load of flooding seems to be fundamental for the damage pattern on buildings particularly for mountainous regions like the European Alps (e.g., Totschnig and Fuchs, 2013). In case of torrent processes, such as fluvial sediment transport (e.g., Totschnig et al., 2011) or debris flows (e.g., Fuchs et al., 2007), debris actions, such as the deposition of the accumulated sediment material, influence the relation on building losses remarkably (Totschnig and Fuchs, 2013).
Nevertheless, for larger mountain rivers like the Austrian Lech River no study analyzed the general applicability of flood damage models so far as previous investigations aimed mainly on dynamic floods of steep torrent streams (see Totschnig and Fuchs, 2013 for an overview). Hence, it is still an open question to which extent depth-damage functions which are mainly developed for lowland areas can be applied in mountainous regions where floods are characterized by a more dynamical impact. In more general terms, the overall applicability and transferability of flood models to other geographical regions is scarcely investigated and thus still compose a major gap in current flood damage modeling research (Thieken et al., 2008; Merz et al., 2010; Jongman et al., 2012; Meyer et al., 2013). What most damage models have in common is that they have been derived for a certain study area with specific regional building characteristics and further specific relationships between losses to buildings and flood impact factors; reliable model application is assumed to be restricted to its region of origin (Oliveri and Santoro, 2000; Kang et al., 2005; Luino et al., 2009; Merz et al., 2010; Papathoma-Köhle et al., 2011). Thus, these models cannot be easily transferred to other regions without any model adaptation and validation (Merz et al., 2010; Papathoma-Köhle et al., 2011; Meyer et al., 2013) as building types, their asset values and their quality differ in other parts of the world. The evaluation of the flood loss model performance is, however, hardly investigated due to the lack of reliable real damage data (Thieken et al., 2008; Merz et al., 2010; Jongman et al., 2012; Meyer et al., 2013).

In general, the associated uncertainty of damage estimates arises from the development of the damage curves, the underlying asset values as well as the applied methodological framework: the spatial scale, cost basis or damage-function type (Merz et al., 2010; de Moel and Aerts, 2011; de Moel et al., 2012; Jongman et al., 2012). According to Apel et al. (2009) and de Moel and Aerts (2011), the largest impact on damage estimation is caused by the shape of the applied depth-damage curve as well as the associated asset values, while the accuracy of the hydraulic input is of minor importance. Although uncertainty in flood damage modeling has to be reduced to make the results more reliable and the models more confident, research on model validation and transferability is still rare (Thieken et al., 2008; Merz et al., 2010; Papathoma-Köhle et al., 2011; Jongman et al., 2012; Meyer et al., 2013). To our knowledge, only few studies have performed a flood loss model validation like in the work of Thieken et al. (2008), Apel et al. (2009), Wuensch et al. (2009), Seifert et al. (2010) or Jongman et al. (2012). Others relied on model intercomparisons (e.g., Bubeck et al., 2011; de Moel and Aerts, 2011) but did not validate the model performance with real damage data. In the case of mountainous areas, flood loss estimation was only validated for torrent processes (e.g., Totschnig and Fuchs, 2013) but no study addressed larger mountain rivers so far. 
This study therefore aims at investigating and evaluating the transferability of various flood damage models to an Austrian region located in the Eastern European Alps. Thereby commonly applied stage-damage functions of previous studies in lowland areas, such as MURL (2000), ICPR (2001) and Hydrotec (2002), as well as newly derived depth-damage functions (linear, square root and polynomial approach) for the residential sector are used to estimate direct structural damage to buildings that was observed during the latest flood event in August 2005. Additionally, the multi-parameter flood loss model FLEMO (Thieken et al., 2008) is adapted to this study area to test its applicability and transferability to another geographical region. In contrast to recent studies (e.g., de Moel and Aerts, 2011 and Jongman et al., 2012) identical, site-specific asset values (but also accounting for intrinsic uncertainty) are used for all relative loss functions to single out the sole impact of damage model selection. To illustrate the effect of model choice on the resulting uncertainty of damage estimates, the current flood risk for residential areas is assessed. Thereby all 57 specific model combinations (including also the uncertainty bound of the sitespecific asset values) are studied to explore the range of plausible, i.e., successfully validated, and all model combinations (including the not successfully validated models).

The test protocol in regard to the spatial model transferability followed the assumption that damage estimates are more reliable if the basic data from which the damage function/model are derived, are more similar (in the sense of more similar building and flood characteristics) to the region under study. For this, two data sets - a heterogeneous data set from Germany and a more homogeneous data set from the adjacent German federal state of Bavaria - were used to derive new damage models apart from the three applied standard stage-damage functions. The performance of the various damage estimates was judged by means of official loss data from the government and hydraulic simulations of the flood event in 2005.

\section{Data and methods}

\subsection{Study area and flood event in 2005}

The study area is the Alpine Lech catchment in the northwestern part of Austria, mainly located in the federal state of Tyrol (Fig. 1) (i.e., nearly $90 \%$ of the Austrian catchment area up to the to the district capital Reutte). This watershed in the Eastern European Alps has a size of $1000 \mathrm{~km}^{2}$ (Dobler et al., 2010) up to that city (gauge Lechaschau/Reutte) which is on the boarder to Germany. In the mountain basin of Reutte the flat valley bottom has its largest extent within the Austrian Lech catchment. There, most of the workplaces are provided in the service sector and in the industrial sector, as the agricultural sector decreased remarkably in the last decades (Amt der Tiroler Landesregierung, 2008). Residential areas

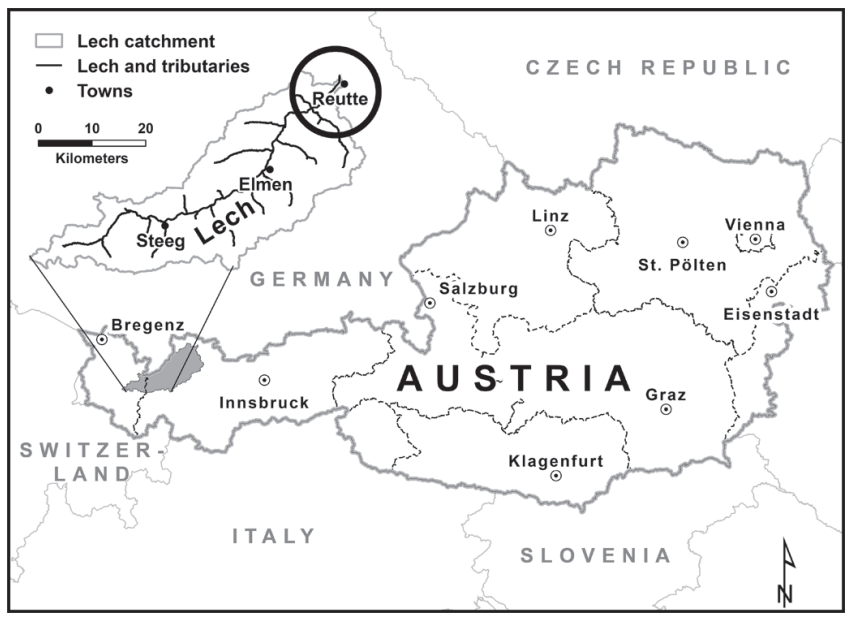

Fig. 1. Geographical overview of the study area in Austria.

have expanded strongly (e.g., by $60 \%$ between 1971 and 2006) mainly at the expense of intensively used grassland (Cammerer and Thieken, 2013). In the same period, the population in the seven investigated riparian municipalities of the Lech River grew intensively, i.e., by $62 \%$ in the municipality of Pflach (for more details see Cammerer et al., 2013). This study is also limited to the analysis of these seven municipalities in the mountain basin of Reutte.

The Lech River, a tributary of the Danube River, affected this settlement area several times with severe flooding in the recent past (Kröll, 2007; Cammerer and Thieken, 2013). Especially the flood events in 1999 and 2005 led to large inundations and flood losses despite various structural flood protection measures (Cammerer and Thieken, 2013). While the monthly average discharge between 1971 and 2000 at the gauge Lechaschau amounted to $45 \mathrm{~m}^{3} \mathrm{~s}^{-1}$ (Dobler et al., 2010), the peak flows of 1999 and 2005 reached $855 \mathrm{~m}^{3} \mathrm{~s}^{-1}$ and $943 \mathrm{~m}^{3} \mathrm{~s}^{-1}$, respectively (Cammerer and Thieken, 2013).

The last flood event in August 2005 with an estimated return period of $330 \mathrm{yr}$ at this gauge (Thieken et al., 2011) hit, in particular, the municipalities of Pflach and Höfen in the study area since overtopping and breaches of embankments caused rapid flooding with large water depths (BMLFUW, 2006; Kröll, 2007). This flood event was triggered by a socalled Vb-similar weather pattern (van Bebber, 1898) with prolonged intensive rainfall combined with already saturated soil leading to high discharges at many Tyrolean gauges (Amt der Tiroler Landesregierung, 2005) causing an estimated direct loss of EUR $410 \mathrm{~m}$ (with $61 \%$ of the total loss in the private sector) in the entire federal state of Tyrol (Amt der Tiroler Landesregierung, 2006). Vb-weather situations are responsible for $12 \%$ of heavy precipitation events in Austria (Seibert et al., 2007) causing frequently severe summer flooding in Europe (Mudelsee et al., 2004). Thereby a cyclone is developed south of the European Alps transporting relatively slowly a large amount of humidity from 
the Adriatic Sea in the northeast direction accompanied by large amounts of rainfall (van Bebber, 1898; Mudelsee et al., 2004; Seibert et al., 2007). In August 2005, several catchments in western Austria where affected by torrent processes with its associated sediment transport or geomorpholocial processes such as landslides (BMLFUW, 2006). But larger mountain rivers, such as Inn or Lech, were also characterized by intensive bed load transport in the headwaters with large destruction on the river channel and infrastructure as a consequence (BMLFUW, 2006). In downstream parts, such as in the lower Lech Valley, however, the sediment transport was particularly reduced due the widening and renaturation of the Lech River (BMLFUW, 2006) in frame of the EU project LIFE (http://www.naturparktiroler-lech.at). Therefore, the flood type can be regarded as an interaction of static and dynamic flooding in this area than a pure dynamic flooding such as in the upper Lech Valley.

\subsection{Simulation of the flood event in 2005}

In order to investigate the applicability and transferability of different loss functions to the Austrian study area the flood event and observed structural damage in 2005 in the residential sector was simulated. For that, a variety of relative damage functions, which are further explained in Sect. 2.3.2, were applied based on site-specific asset values for residential areas and additional information like level of contamination for the extended models (Sect. 2.2.3) as well as the simulated maximum water depths of the event in August 2005 (Sect. 2.2.1). The outcome of each loss function is finally validated by means of official flood loss data from the Tyrolean government (Sect. 2.2.2).

\subsubsection{Flood hazard information}

Besides the determination of residential properties relative damage functions also require information about the flood hazards to relate damage to property with the characteristics of inundation. For the simulation of the maximum water depths of the flood event in August 2005 we performed a hydrodynamic-numeric modeling by means of the twodimensional model Hydro_AS-2D (Nujic, 2003). Originally developed for dike breach and flood wave propagation the model is increasingly used for river flood analysis (Noack and Yörük, 2008) and is applied as a standard system for flood routing in the neighboring federal state of Bavaria (Germany). While the spatial discretization is based on the finite-volume method, the temporal discretization is solved by the Runge-Kutta method (for details see Nujic, 2003). The model has the advantage that linear triangular and quadrangular elements can be used with different spatial resolution in order to consider discharge relevant structures like dikes, streets, etc. (e.g., Noack and Yörük, 2008). The mesh with a length of ca. $10 \mathrm{~km}$ consists of a river channel model integrating 40 cross section profiles and a flood plain model based on laser scanning data with a spatial resolution of $1 \mathrm{~m}$. Hydraulic relevant structures like bridges or structural flood protection measures (e.g., the flood wall that protects the municipality of Lechaschau) were also considered in the terrain model. The simulation of the flood event in 2005 was carried out by adapting the structural protection measures to the situation before the flood in 2005. The hydrologic boundary conditions were adjusted for the inlet discharge according to the discharge at the gauge Lechaschau. Finally, the two-dimensional simulations were performed with the flood wave observed in August 2005.

In order to assess the model performance, the simulated water depths were compared with observed water marks acquired from the engineering office "DonauConsult" (http://www.donauconsult.at) recorded one month after the flood by means of leveling of flood level marked stones, bridges or buildings (DonauConsult, personal communication, June 2011). In addition to the water marks, the flood extent was compared with the flood extent mapped by Ebner et al. (2007) in the southern part of the study area, which is based on oblique aerial photos taken by the Austrian Armed Force during the flood event in August 2005. While the model validation was performed by means of the simulated water levels (in $\mathrm{m}$ a.s.l.) on a $1 \mathrm{~m} \times 1 \mathrm{~m}$ grid, the corresponding water depths (in $\mathrm{m}$ above ground surface) were aggregated on a cell size of $10 \mathrm{~m}$ by using the mean of the input cells for the intersection with the asset values ( $10 \mathrm{~m}$ cell size) in frame of the damage modeling.

For the flood event in 2005 two hydraulic-simulation runs were considered. Since in 2005 levee failures occurred in the community of Pflach (Kröll, 2007), the dikes were artificially opened at two breach locations in the simulation run "23a". In the simulation run " $22 \mathrm{a}$ ", in contrast, the same terrain model is used but no dike breach location was included. In addition to the two simulation runs for the 2005-flood, further hydrodynamic simulations were carried out for discharges that represent the current statistical flood return period of 30 , 100, 200 and $300 \mathrm{yr}$. In these simulations, the recent improvements of the structural protection measures were already considered (e.g., heightening of the levees at the community of Pflach).

\subsubsection{Official flood loss data of 2005}

In Austria, loss data of flood events are generally collected in frame of the loss compensation by the national Disaster Fund (Katastrophenfonds), which was established in 1966 in the aftermath of a series of natural disasters in the Austrian Alps and revised in 1996 (Habersack et al., 2004; Holub and Fuchs, 2009). Thereby the single federal states are responsible for the data collection and loss compensations for private households and companies due to natural hazards. This is one of the main tasks of this fund apart from the financial support for the construction and maintenance of structural flood and avalanche defense measures (Holub and Fuchs, 2009). 
As the responsibility of the financial support in frame of the disaster fund is assigned to the single federal states, different approaches exist for loss compensation and loss recording (Habersack et al., 2004). In some federal states, losses are not explicitly documented with regard to the damaging process (flood, debris flow etc.), the object at risk (e.g., residential building or industry), or the damage to building and household contents, for instance (Habersack et al., 2004). Likewise, each federal state has its own guidelines which determine the extent and content of the financial assistance (Habersack et al., 2004). In Tyrol, for example, an average loss compensation of $20 \%$ of the total damage to buildings and contents can be received by the affected parties (Habersack et al., 2004) as long as no insurance indemnities were paid out which are subtracted before loss is compensated by the disaster fund (Habersack et al., 2004; Holub and Fuchs, 2009).

For this study, anonymized loss data of the national Disaster Fund for the seven investigated municipalities in the area of Reutte were provided by the Tyrolean government. At first, these data were shaped to our usage by extracting only the loss reports where damage could be traced back due to a flood and where only residential buildings (and household contents) were affected. However, some flood loss reports could not be divided into structural damage to buildings and damage to household contents since both types were affected and only an aggregated loss was recorded. We assumed that in case of such a cumulative damage the share of damage to household contents amounted to $30 \%$ of the total loss. This value was taken from the loss documentation guidelines of the federal state of Lower Austria (Amt der NÖ Landesregierung, 2012).

To compare the observed structural damage to residential buildings (EUR $1.9 \mathrm{~m} ; n=70$ cases) with the flood loss model estimates using building values of the year 2006 (Sect. 2.2.3) the anonymized and separated building loss data of the national Disaster Fund were indexed to the reference year 2006 by means of the construction cost index of Statistics Austria (2013a). Lastly, a resampling of all building loss records was carried out by means of bootstrapping with 10000 simulated random samples which were drawn by replacement from the structural loss records. The 2.5 th and 97.5th percentile of the total building loss as well as the mean (and median) total damage of these samples were used to obtain a $95 \%$ confidence interval of the observed structural losses. Following the work of Thieken et al. (2008), loss estimates that fall within the $95 \%$ interval of the resampled data were assumed to be acceptable, whereas others can be rejected. By this approach it is possible to evaluate the performance and transferability of the applied damage models for the estimation of structural damage in residential areas.

\subsubsection{Asset values and additional data for the extended models}

Asset values are an important prerequisite when flood losses are calculated on the basis of relative damage functions (Wuensch et al., 2009; Merz et al., 2010). Depending on the scale of investigation, single object values (microscale) or aggregated information (meso- and macroscale), such as on municipality level, are required (Wuensch et al., 2009). To bridge the gap between explicit hazard data, such as water depths and coarse information of the asset values (e.g., municipality or district level), a disaggregation has to be performed (e.g., Thieken et al., 2006; Wuensch et al., 2009). Therefore, ancillary information with a higher resolution, such as land use data, are commonly applied to transfer the aggregated (municipal) values to a higher spatial resolution (Merz et al., 2010). Object-based studies, on the other hand, evaluate each element at risk by assigning average economic values to buildings using the volume and type of building (e.g., Keiler et al., 2006; Fuchs et al., 2007) or the building size and number of storeys (e.g., Totschnig et al., 2011; Totschnig and Fuchs, 2013).

In this study, we rely on a land use map of 2006 for attributing aggregated asset values to residential areas. This land use map was derived on the basis of the visual interpretation of true color orthophotographs (RGB) provided by the Tyrolean government. The land use data set of 2006, applied in previous studies of Cammerer et al. (2013) and Cammerer and Thieken (2013), differentiates between nine land use classes on a spatial resolution of $50 \mathrm{~m}$. For the estimation of the asset values of residential areas, we assigned aggregated replacement values of 2006 provided by Huttenlau and Stötter (2008) to the land use type "residential area" of Cammerer et al. (2013). Thereby the aggregated replacement values of buildings on the municipal level were divided by the residential area of each municipality of the land use map 2006 to obtain specific replacement values (EUR per $\mathrm{m}^{2}$ ). In fact, these replacement values based on representative mean insurance values (see Huttenlau and Stötter, 2008 for details) overestimate the damage as they assume that the damaged object has to be replaced by a similar, new object (Merz et al., 2010). However, this assessment concept which is usually applied in insurance analyses to follow the adjustment of claims by insurance companies, fits more in the scope of this study since the observed loss in Sect. 2.2.2 also represents compensation payments (of the government) for property damage on affected buildings (cf. also the studies of Fuchs et al. (2007) or Totschnig et al. (2011) for Austria). But for project appraisals, such as cost-benefit analyses of mitigation options, the concept of depreciated values has to be used as it considers the continuous depreciation of the object by its use and provides an estimate of the economic present value (Merz et al., 2010). For the damage estimation, we used an average replacement value for residential areas of EUR 279 per $^{2}$ for the whole study area which is very 
similar to the specific values (building fabric) for residential areas of the Rhine Atlas (ICPR, 2001) for different neighboring countries. Additionally, the minimum (EUR 224) and maximum (EUR 353) specific replacement value was used to account for uncertainty in sense of valid parallel models (Merz and Thieken, 2009). These threshold values represent the lower and upper boundary of the different specific asset values between the single municipalities when no average value is used for the whole study area. A comparison of this range of asset values with other studies carried out in Austria is not possible without further ado. The work of Keiler et al. (2006) or Totschnig et al. (2011), for instance, indicate only object-based values for dwellings (e.g., EUR 1670 per $\mathrm{m}^{2}$ of the building size; Totschnig et al., 2011) which, however, need to be converted to area-specific values (e.g., Jongman et al., 2012) to make these values comparable.

\subsection{Derivation and adaptation of the flood loss models to the study area}

\subsubsection{Data basis for the flood loss functions}

Since more detailed flood loss data of past events have hardly been collected in Austria or do not contain the relevant information to relate the flood losses to a certain water depth (Habersack et al., 2004), we used a comprehensive flood loss database from Germany as a basis for the derivation of various flood loss functions and the multi-parameter loss model. These loss data were collected in the aftermath of flood events in Central Europe in 2002, 2005 and 2006 affecting the catchments of the rivers Elbe and Danube. Thereby two surveys with computer-aided telephone interviews were carried out in flood-affected private households in Germany. In the first campaign in 2003, 1697 private households in the German federal states of Bavaria, Saxony and SaxonyAnhalt, which were affected by flooding in August 2002, were interviewed. This data set contains not only loss information from the Elbe River where the floodwater raised slowly (static flood type) but also from its tributaries in the Erzgebirge (Ore Mountains) characterized by flash floods (dynamic flood type) and from the Danube catchment where both flood types occurred (Kreibich et al., 2005; Thieken et al., 2007). Apart from flood losses on residential buildings and household contents, potential flood damage influencing factors like water level, flood duration, contamination, precautionary and emergency measures were recorded in frame of this survey (for a more detailed description of this campaign see Thieken et al., 2005, 2007). At the end of 2006, a similar campaign was conducted among 461 private households which were hit by floods in Bavaria in August 2005 or along the Elbe in March/April 2006 (for more details see Kreibich and Thieken, 2009 and Kreibich et al., 2011a). The majority of the interviews $(\sim 70 \%)$ in the second survey were conducted in Bavaria which was affected stronger in financial terms than the Elbe catchment in the following year (Kreibich et al., 2011a).
From this merged database with a total of $n=2158$ cases, we first calculated the building loss ratios (i.e., the relative damage). For this, the absolute financial damage to buildings was indexed to the reference year 2006. In addition, the indexed total value of buildings (replacement costs) was calculated as described in detail by Thieken et al. (2005) and Elmer et al. (2010). As not all interviews contained sufficient information for the calculation of the loss ratio for residential buildings these relative losses were only available for 1121 cases. From this data set we considered two subsets which were further used for the model development: the first German-wide data set comprises all cases from both surveys, in which damage ratios were available; this heterogeneous subset contained 1121 cases from different regions in Germany. The second data set is constrained to the cases from the federal state of Bavaria, further called Bavarian sample, resulting in 415 flood affected households with loss ratios. Regarding the flood impact (i.e., the exceedance probabilities) in the first survey, the flood event in 2002 was more severe in the Saxon Elbe catchment $(T>100)$ than in the Bavarian Danube catchment $(T<100)$ (see Thieken et al., 2007 and Thieken et al., 2010 for more details). In the second survey, in contrast, the Bavarian part was faced with a stronger flood impact ( $T=50-100)$ in 2005 than Saxony in 2006 with $T=10-20$ (Thieken et al., 2010). Thus, the mean absolute building damage of both surveys is considerably higher in Saxony than in Bavaria, presumably due to the more extreme flood event character in 2002 (Thieken et al., 2010).

Nevertheless, due to the adjacent location of Bavaria to our study area, we hypothesize that the derived loss functions of the Bavarian subset may yield more reliable estimates because, assumably, building and flood event characteristics are more similar to related damage patterns than functions derived from data of more dissimilar and different geographical regions. This assumption is supported by findings from, for example, Oliveri and Santoro (2000), Dutta et al. (2003) and Kang et al. (2005).

\subsubsection{Derivation of the flood loss models}

Since relative stage-damage curves have the advantage of a better transferability in space and time (Oliveri and Santoro, 2000; Merz et al., 2010), we follow a relative (empirical) approach in this study. Apart from the application and derivation of different simpler stage-damage functions, a further goal of this study was also the adaptation of a multiparameter model to this investigation area as they tend to improve the reliability of flood damage modeling (Meyer et al., 2013).

On the one hand, we use three relative stage-damage functions for the residential sector already elaborated in previous studies in Germany, i.e., MURL (2000), ICPR (2001) and Hydrotec (2002). In the first model, the loss ratio of residential buildings is calculated by the linear function $y=0.02 \times x$, where $x$ is the water depth in meters and 
$y$ the loss ratio (MURL, 2000). In case of water levels higher than $5 \mathrm{~m}$, the damage ratio is set to $10 \%$ (MURL, 2000). This model was derived for the Lower Rhine area in Germany using loss data from the German flood damage database HOWAS (Merz et al., 2004) and evaluates relative building losses independently from losses to inventory. The HOWAS database contains object-specific loss data (replacement costs) of 4000 buildings (i.e., private households, manufacturing, service sector etc.), caused by nine flood events between 1978 and 1994 in different regions (but mainly in the southern part) of Germany (Merz et al., 2004; Thieken et al., 2010). This database was also used to derive the function of Hydrotec (2002), applied in frame of the flood action plan for the German Lippe catchment. Thereby a square root function with $y=(27 \sqrt{ } x) / 100$ is used to estimate the relative loss on residential buildings. In contrast to these both approaches, the second model (ICPR, 2001) uses additionally some synthetical what-if data derived by experts (e.g., engineers) to describe the resulting loss ratio by the function $y=\left(2 x^{2}+2 x\right) / 100$. This model was developed for the Rhine Atlas where flood damage was assessed for different land use types in the whole Rhine catchment (ICPR, 2001). All three loss models have in common that they were derived for lowland regions which implies that the water level as main determinant for flood damage is rather slowly rising.

On the other hand, we used newly derived damage functions in accordance to our test protocol assuming that loss estimates perform better if the underlying models are derived from related and geographical more adjacent areas. Like in the previous functions, we also used a linear, a square root as well as a polynomial stage-damage curve which are often suggested in flood loss estimation (e.g., Büchele et al., 2006; Kreibich and Thieken, 2008; Elmer et al., 2010). As contamination seems to affect flood losses decisively (e.g., Nicholas et al., 2001; Kelman and Spence, 2004; Kreibich et al., 2005; Penning-Rowsell et al., 2005; Thieken et al., 2005, 2007; Kreibich and Thieken, 2008) and its consideration yields in more accurate loss estimations (e.g., Thieken et al., 2008; Prettenthaler et al., 2010), we separated these functions regarding the contamination of flood water in an additional stage. As a data basis for the derivation of the six stage-damage functions (with and without consideration of contamination) we used the whole data set from different regions in Germany and the Bavarian subset that were introduced in Sect. 2.3.1. In contrast to the three standard functions above, focusing on lowland rivers like the lower Rhine etc. the underlying data for the newly derived functions were partly collected in mountainous regions like the Erzgebirge (Ore Mountains) or in the Bavarian Danube catchment (see Sect. 2.3.1), where also dynamic flooding with higher flow velocities occurred. Consequently, these new functions may not only be applicable for static flooding, but may also be usable for mixed flood types like in the mountainous region of Reutte.
Lastly, the multi-factorial flood loss model FLEMO (Thieken et al., 2008) was adapted to the Austrian study area. This empirical model was originally developed on the basis of collected flood loss data in the aftermath of the flood event in 2002 in Germany. In its basic stage, it assesses the direct monetary damage to residential buildings by differentiating between five classes of water depth, three residential building types and two building qualities (Büchele et al., 2006; Thieken et al., 2008). In an extended model stage (FLEMO+) three classes of contamination and three classes of private precaution are additionally included. The model is applicable on the microscale, i.e., on the object level, as well as on the mesoscale, i.e., on homogeneous land use units. For both scales it was successfully validated (Thieken et al., 2008) and applied or modified in different studies (e.g., Kreibich and Thieken, 2008; Apel et al., 2009; Merz and Thieken, 2009; Wuensch et al., 2009; Elmer et al., 2010; Kreibich et al., 2011b; Merz et al., 2013).

In this study, FLEMO is applied on the mesoscale by modifying the required input parameters to the Austrian study area. This adapted model is called FLEMO $_{\mathrm{AT}}$ and FLEMO $_{\mathrm{AT}+}$ in what follows. In Austria, the building type is not classifiable in one-family, (semi-)detached or multifamily house a priori, when referring to the official statistical data (Statistics Austria, 2013b). There, residential buildings are only differentiated by the number of included apartments per building, e.g., buildings with 1-2 apartments, 310 apartments etc. Nevertheless, by means of some auxiliary calculations it was possible to introduce an almost similar classification scheme for the adapted model version. Thereby the building type is differentiated between onefamily houses, two-family houses (which may include some (semi-)detached houses, but also multi-story houses with two apartments) and multi-family houses (i.e., more than two families/apartments within one building).

The building quality in Austria is differentiated in four classes (Statistics Austria, 2013b) and is adapted to the two different classes applied in Germany, i.e., low/medium quality and high quality, by assigning the lower three building quality categories (Ausstattungskategorie der Wohnungen B$D)$ to low/medium quality and the highest category (Ausstattungskategorie der Wohnungen A) to high building quality.

The level of private precaution and contamination for the extended model stage FLEMO $_{\mathrm{AT}+}$ could not be realized as detailed as in the original model version of Thieken et al. (2008). In the Austrian model version, only four combinations of contamination (yes/no) and precaution (yes/no) are differentiated. Contamination is the fact, that private households were affected by contamination of the flood water due to sewage, chemicals, oil and/or petrol. Precaution was assumed to be in place when households implemented "floodadapted building use" (i.e., the cost-extensively usage of flood-prone storeys) and/or "flood adapted interior fitting" (i.e., the usage of water-repellant materials such as tile floor instead of parquet or movable furniture in affected storey, for 
example) before the flood event since these two building precautionary measures turned out to be very effective (for details see Kreibich et al., 2005; Cammerer and Thieken, 2011). However, in this context it has to be stated that these both measures may not necessarily be as effective in the study area as in the lowland rivers where the flood impact is more static. According to Holub et al. (2012) other structural protection measures like reinforcement of the outer walls or elimination of building openings at ground surface level may be more promising in mountain environments particularly for fluvial sediment transport related to torrents with dynamic flow conditions and high sediment concentrations. Nevertheless, since the mountain basin of Reutte is very flat and the flood impact in 2005 was not characterized by large material deposits in this area (BMLFUW, 2006), we assume that these two precautionary measures are also valuable in this mountain region since its benefit was also tested with loss data from the Erzgebirge (Ore Mountains) (e.g., Kreibich et al., 2005). The derivation of the loss functions (basic model stage) and the scaling factors (Büchele et al., 2006) (for the extended model stage) are finally performed for both subsets separately (i.e., the German data set and the Bavarian sample). Like in case of the newly derived functions both underlying subsets contain loss reports from regions where not only static but also dynamic flooding occurred as observed in the study area of Reutte.

For the extended damage functions (consideration of contamination) as well as for the adapted model FLEMO $_{\mathrm{AT}+}$ information about contamination and private precaution was gathered by means of the study of Raschky et al. (2009) since the loss reports of the Disaster Fund give no hint about the share of contamination/precaution in the study area. Thereby 218 interviews in private households in the Austrian federal states of Tyrol and Vorarlberg were carried out in the aftermath of the flood event in 2005 in order to compare different risk transfer systems of three Alpine regions being affected of this large flood event (Grisons (Switzerland), Tyrol (Austria) and Bavaria (Germany)). Among various questions, also the level of private precaution and contamination (similar to the two campaigns of Sect. 2.3.1) was questioned. While all interviewed households did respond to questions concerning their precautionary behavior, less people provided information on the level of contamination, since only 72 of all surveyed households were actually affected by the flood in 2005 (Raschky et al., 2009). Nevertheless, this information enabled us to determine contamination occurrence and precaution in private households in the district of Reutte.

An important prerequisite for the derivation of the loss functions is that the building loss ratios between the single subclasses, for example between both contamination types, differ significantly. Statistical differences between two independent subclasses were tested by the Mann-Whitney $U$ test and by the Kruskal-Wallis $H$ test for three subclasses and more. In case that the subclasses differ significantly $(p<0.05)$ the corresponding loss ratios are derived for each
Table 1. Error statistics for two simulation runs of the flood event in 2005. Note: the "flood area index" was only calculated for the southern part of the study area (DEM "22a": dike heights as in 2005; DEM "23a": dike heights as in 2005 but artificially opened at two breach locations at the municipality of Pflach as described by Kröll, 2007).

\begin{tabular}{lrrrr}
\hline $\begin{array}{l}\text { Digital } \\
\text { elevation } \\
\text { model (DEM) }\end{array}$ & $\begin{array}{r}\text { Bias } \\
(\mathrm{m})\end{array}$ & $\begin{array}{r}\text { Mean } \\
\text { absolute } \\
\text { error (m) }\end{array}$ & $\begin{array}{r}\text { Root mean } \\
\text { square } \\
\text { error }(\mathrm{m})\end{array}$ & $\begin{array}{r}\begin{array}{r}\text { Flood } \\
\text { area index } \\
(\%)\end{array} \\
\hline \text { 22a }\end{array}$ \\
$23 \mathrm{a}$ & 0.31 & 0.38 & 0.51 & 83.8 \\
\hline
\end{tabular}

subclass. Otherwise, this variable is not considered as input parameter in the extended/adapted flood loss model. Furthermore, all stage-damage curves were calculated based on the water level above ground surface by setting water levels below ground surface (cases where only the basement was affected) to zero.

The final damage estimation is done on a grid basis. First, the asset map is intersected with the hydraulic scenario which results in the potentially affected assets. Then the loss ratio is determined per grid cell and finally multiplied with the asset value of the corresponding grid cell to obtain the absolute structural monetary damage to residential buildings. Grid estimates are summarized per municipality and finally for the whole event.

\section{Results}

\subsection{Validation of the hydraulic simulations}

The validation of the hydraulic modeling was carried out by means of the recorded water marks and the mapped flood extent of the flood in 2005. It has to be noticed that two measurements out of all 13 georeferenced recorded water marks were assumed to be erroneous as their georeferenced locations did not agree with the corresponding verbal description of their location. Due to this supposed shift in the coordinates, both marks were left out. The deviations between the remaining eleven recorded and georeferenced watermarks (Fig. 2) and the simulated maximum water levels at these points are small; they are summarized by different error statistics in Table 1 . The bias amounts only to $0.31 \mathrm{~m}$ in both simulation runs which is slightly larger when the mean absolute error (MAE) is used. With respect to the root mean square error (RMSE), which emphasizes larger deviations, the total error in both runs is also acceptable $(0.51 \mathrm{~m})$. The error statistics at the eleven compared water marks indicate therefore a reasonable fit of the hydraulic model. 


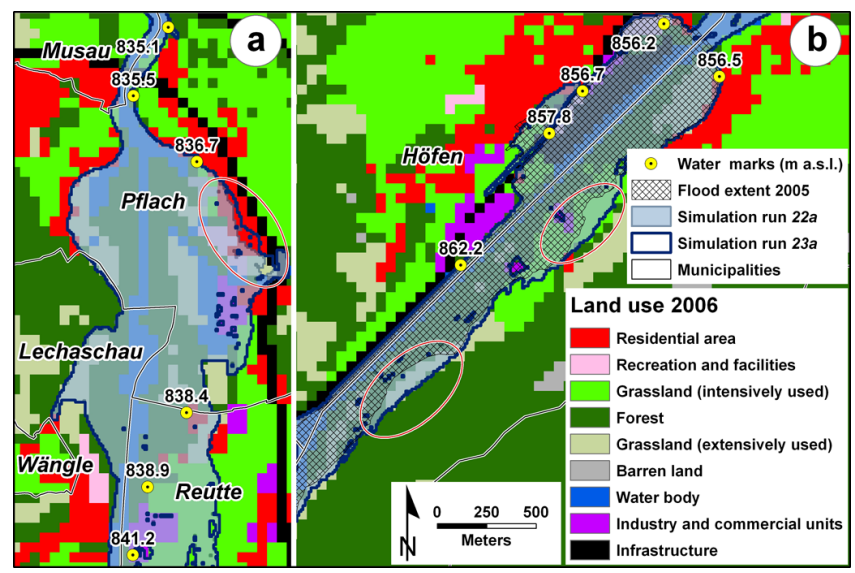

Fig. 2. Comparison of the recorded water marks and the mapped flood extent of the flood event in 2005 with the two hydraulicsimulation runs "22a" (dike heights as in 2005) and "23a" (dike heights as in 2005 but considering dike breaches) in the northern (a) and in the southern part (b) of the study area. The red circle in figure (a) illustrates the location of the difference in the flood extents at the community of Pflach between both runs. The red circles in figure (b) display the differences between the observed and modeled flood extents in the southern study area.

As a quality measure for the modeled flood extent, we calculated the "Flood Area Index" (Table 1), which is one of the most recommended measures in the literature (e.g., Apel et al., 2009; Dung et al., 2011). Since the aerial photos were recorded two days after the peak discharge and were not available for the northern part of the study area (Fig. 2a), where the largest inundation occurred, the mapped extent has, however, some shortcomings as quality criterion and therefore serves only as a rough estimate. Thus, the rather low value of $84 \%$ (Table 1) which seems to be insufficient can be refuted due to the shortcomings of the mapping procedure outlined by Ebner et al. (2007). Nevertheless, this index gives a rough estimate that both simulation runs may hit the observed flood extent sufficiently with little differences in the outlines of the flood extent (Fig. 2b, red circles). Although it was not possible to compare both simulation runs quantitatively in the northern part at the community of Pflach where the two runs differ distinctly (Fig. 2a, red circle), we conclude that simulation run " $23 \mathrm{a}$ " is more plausible due to the consideration of the observed dike breaches. Nevertheless, we use both simulation runs for the further analysis as the quantitative validation results are equal.

Regarding the distributions of the inundation depths within residential areas (Fig. 3), the two simulation runs differ particularly in the range of lower $(0.5-0.8 \mathrm{~m})$ and higher $(2.2-$ $3.0 \mathrm{~m}$ ) water depths. The larger share of higher water depths in simulation "23a" results from the dike breach locations where larger parts of residential area were flooded (Fig. 2a) in contrast to run " $22 \mathrm{a}$ " where only overtopping effects occurred in this area. Therefore the distribution of run " $22 \mathrm{a}$ "

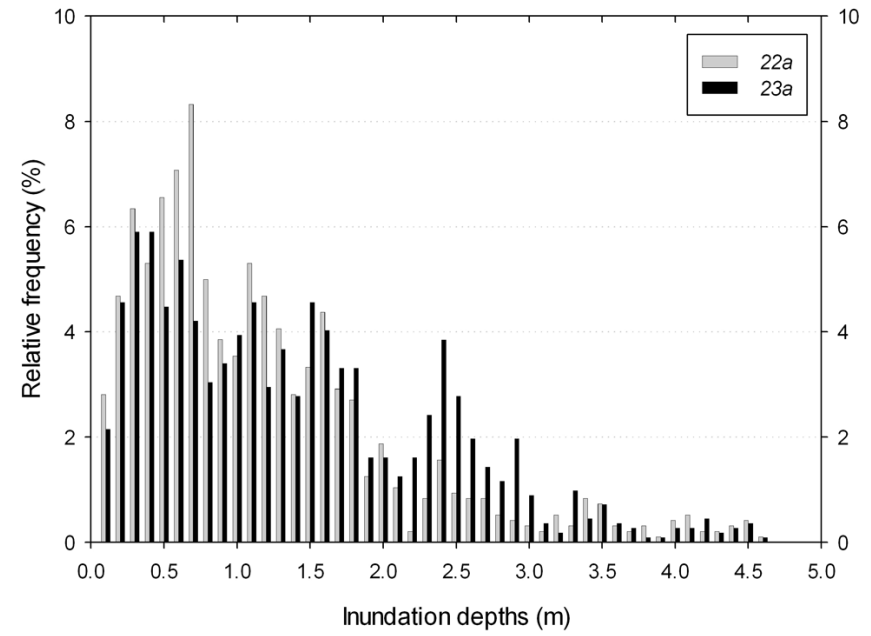

Fig. 3. Relative frequencies of the water depths (within a $10 \mathrm{~cm}$ interval) in August 2005, simulated by the two hydraulic-simulation runs "22a" (dike heights as in 2005) and "23a" (dike heights as in 2005 but considering dike breaches). Note: only inundated grid cells within residential areas are analyzed in this histogram.

shifts to a higher share of lower water depths which will consequently affect the damage estimates of both runs.

\subsection{Statistical analysis of the flood losses and the derived loss functions}

The statistical analysis of the two data sets derived from the surveys in large parts of Germany and in the federal state of Bavaria reveals that, in general, the variation and the mean average of the loss ratios in private households of the mixed subset is larger compared to the Bavarian sample (Table 2). This may be explained by the larger heterogeneity of the German-wide data set, collected in different geographical regions and from various flood events with different impacts and process characteristics. As pointed out by Thieken et al. (2005) specific building characteristics, for instance, may affect the specific relationships between losses to buildings and flood impact factors leading to a large variation of damage data in more heterogeneous regions (Luino et al., 2009; Merz et al., 2010). This assumption is also supported by our results.

When the flood losses are subdivided into different water levels, the loss ratios between the five water level classes applied in $\mathrm{FLEMO}_{\mathrm{AT}}$ differ significantly in both data sets. As expected, mean damage to buildings increases with rising water levels, since water depth is identified as the most dominant influencing factor on flood damage (Thieken et al., 2005). The variation within the single water level classes is, however, again higher in the larger subset, particularly above a water depth of $1 \mathrm{~m}$ (Table 2). Loss ratios between the three building types are also significantly different in both subsets, especially in case of one-family houses which have, however, the highest share in the study area $(60 \%)$. The building 
Table 2. Statistical characteristics of the flood damage ratios of the German-wide subset ${ }^{\mathrm{a}}$ and the Bavarian subset ${ }^{\mathrm{b}}$, differentiated between the factors considered in the extended/adapted flood loss functions.

\begin{tabular}{|c|c|c|c|c|c|c|c|c|}
\hline \multirow[b]{2}{*}{ Factor } & \multicolumn{4}{|c|}{ German subset } & \multicolumn{4}{|c|}{ Bavarian subset } \\
\hline & $n$ & $25 \%$-ile & $50 \%$-ile (mean) & $75 \%$-ile & $n$ & $25 \%$-ile & $50 \%$-ile (mean) & $75 \%$-ile \\
\hline All loss reports & 1135 & 1.5 & $5.1(11.1)$ & 15.4 & 420 & 0.5 & $1.9(4.4)$ & 5.2 \\
\hline Water Level & $(*)$ & & & & $(*)$ & & & \\
\hline$<21 \mathrm{~cm}$ & 439 & 0.4 & $1.5(3.4)$ & 3.9 & 247 & 0.3 & $1.2(2.6)$ & 3.1 \\
\hline $21-60 \mathrm{~cm}$ & 137 & 2.0 & $5.1(8.4)$ & 10.5 & 52 & 0.9 & $3.4(6.1)$ & 7.2 \\
\hline $61-100 \mathrm{~cm}$ & 131 & 2.9 & $5.7(9.5)$ & 12.7 & 49 & 1.9 & $3.5(5.6)$ & 7.3 \\
\hline $101-150 \mathrm{~cm}$ & 151 & 6.3 & $13.6(17.8)$ & 25.7 & 29 & 1.9 & $3.4(8.3)$ & 12.0 \\
\hline$>150 \mathrm{~cm}$ & 263 & 8.6 & $17.9(22.4)$ & 31.5 & 38 & 1.9 & $5.6(9.5)$ & 14.3 \\
\hline Building type & $(*)$ & & & & $(*)$ & & & \\
\hline One-family houses & 654 & 1.7 & $6.0(12.4)$ & 19.4 & 230 & 0.8 & $2.1(5.1)$ & 5.9 \\
\hline Two-family houses & 294 & 1.3 & $4.3(9.6)$ & 12.5 & 117 & 0.4 & $1.5(3.8)$ & 4.2 \\
\hline Multi-family houses & 186 & 1.1 & $3.9(8.9)$ & 10.5 & 73 & 0.3 & $1.3(3.1)$ & 4.2 \\
\hline Building quality & & & & & & & & \\
\hline High quality & 1062 & 1.5 & $5.1(11.2)$ & 15.4 & 388 & 0.5 & $1.8(4.4)$ & 5.1 \\
\hline Low/medium quality & 66 & 0.7 & $3.3(9.0)$ & 15.7 & 28 & 0.4 & $2.1(5.1)$ & 8.4 \\
\hline Contamination & $(*)$ & & & & $(*)$ & & & \\
\hline None & 546 & 0.6 & $2.1(6.2)$ & 6.6 & 279 & 0.3 & $1.4(3.2)$ & 3.8 \\
\hline Yes & 579 & 3.6 & $10.9(15.7)$ & 22.4 & 139 & 1.4 & $3.5(6.8)$ & 8.5 \\
\hline Private precaution ${ }^{\mathrm{c}}$ & $(*)$ & & & & $(*)$ & & & \\
\hline None & 868 & 2.0 & $6.9(12.8)$ & 18.3 & 281 & 0.6 & $2.1(5.1)$ & 6.0 \\
\hline Yes & 265 & 0.5 & $1.9(5.4)$ & 5.7 & 137 & 0.4 & $1.3(3.0)$ & 3.5 \\
\hline
\end{tabular}

quality, in contrast, shows no significant differences in the loss ratios of both subsets. Consequently, this input parameter is discarded in the adapted model FLEMO AT $_{\text {. }}$.

The loss characteristics differentiated by contamination underpins the importance of considering the effect of contamination to building damage in flood loss modeling (e.g., Nicholas et al., 2001; Kelman and Spence, 2004). Both subsets show that in case of contamination flood loss differs significantly and are therefore considered in the simpler stagedamage functions as an additional influencing factor. The benefit of private precaution is also illustrated in Table 2 . When one or both of the mitigation measures "flood adapted building use" and/or "flood adapted interior fitting" is implemented, the loss ratios of buildings are significantly lower in both subsets justifying once more the great influence of building precautionary behavior. Even in mountain environments local structural protection measures are able to prevent a considerable proportion of the average structural damage per building, particularly in case of low-magnitude but highfrequency torrent processes (Holub et al., 2012). Thus the mitigation effect of private precaution should also be taken into account for the mountainous region of Reutte.
From all loss characteristics shown in Table 2 it can be concluded that the variation of the different loss ratios within the single subsets are notably larger in the data set that was collected in more distributed regions than in the rather regional data set from Bavaria. Nevertheless, there is also a spatial limit regarding more homogeneous samples from smaller regions for deriving depth-damage functions. As discussed by Chang et al. (2008) spatial autocorrelation influences considerably the relationship between flood depth and resulting damage in small sample areas. Thus it can be assumed that both a large region as well as too small areas may lead to notable variations in the damage data particularly when only flood depth is considered as main influencing parameter. A subsequent differentiation of the Bavarian sample into the same flood event of 2005 (data not shown) did not reduce the variation of the damage data furthermore. This finding is, however, not statistically robust due to the small sample sizes in the smaller subclasses. Therefore the statistical analysis and derivation of the flood loss functions is also a compromise between the data availability and the resulting model performance. 
Table 3. Derived scaling factors for building losses due to private precaution and contamination. Factors for the extended loss model FLEMO $_{\mathrm{AT}+}$ are differentiated between the two subsets from Germany and Bavaria.

\begin{tabular}{lrr}
\hline & $\begin{array}{r}\text { German } \\
\text { subset }\end{array}$ & $\begin{array}{r}\text { Bavarian } \\
\text { subset }\end{array}$ \\
\hline No contamination, no precaution & 0.90 & 0.88 \\
No contamination, good precaution & 0.44 & 0.48 \\
Contamination, no precaution & 1.33 & 1.53 \\
Contamination, good precaution & 0.81 & 0.90 \\
\hline
\end{tabular}

The different loss functions derived from both subsets as well as the three standard functions are shown in Fig. 4. This figure illustrates the range of the damage functions, particularly for the German-wide data set (Fig. 4a and c). However, even in such a heterogeneous data set the newly derived functions lie in closer proximity than the three common stage-damage functions of MURL (2000), ICPR (2001) and Hydrotec (2002), which were derived from the more comprehensive HOWAS flood loss database and expert judgment (Merz et al., 2004). From the newly derived functions the polynomial functions increase strongest in both data sets, while the remaining functions lie close together, especially in the Bavarian subset. Figure $4 \mathrm{c}$ and $\mathrm{d}$ show furthermore the impact of contamination as all functions increase steeper when this factor is included.

In order to account for the local characteristics of contamination and precaution in the study area the proportion of these influencing factors were derived from the Tyrolean survey. The analysis reveals that most of the households $(71 \%)$ in the district of Reutte were not affected by contamination which is slightly higher than in the whole federal state of Tyrol $(68 \%)$ in 2005 . The share of households which did not perform one or both of the very effective building precautionary measures "flood-adapted building use" and/or "floodadapted interior fitting" amounts to $80 \%$, but is a little bit lower than in the whole federal state $(85 \%)$. The proportion of contamination is finally considered for weighting the extended functions to calculate the total damage on residential buildings in the study area. For the extended model FLEMO $_{\mathrm{AT}+}$, the proportions of precaution within the contamination classes were used to multiply the total loss of FLEMO ${ }_{\text {AT }}$ with the derived scaling factors (Table 3 ).

\subsection{Comparison of the modeled flood damage with the observed loss}

The overall reported flood loss to buildings (damage to the building fabric) in the residential sector in 2005 (indexed to 2006) in the area of Reutte amounted to EUR $1.904 \mathrm{~m}$ and EUR $1.885 \mathrm{~m}$ (mean and median of the 10000 bootstrap samples), respectively, whereby the $95 \%$ confidence interval ranges from EUR $1.429 \mathrm{~m}$ (2.5th percentile) to EUR $2.662 \mathrm{~m}$ (97.5th percentile) (Table 4). In comparison to the long-term average damage to buildings for whole Austria (based on the analysis of all flood events between 1991 and 2003) amounting to EUR 21000 (Habersack et al., 2004), the indexed average damage of buildings (of the 10000 bootstrap samples) in 2005 in the study area amounts to EUR 28500 (std.dev.: EUR 4400) which is considerably higher due to the extreme hydrological impact of the flood event in 2005 (see Habersack et al., 2004 for a more detailed flood event description).

The performance of all flood loss models to estimate the total building damage of the 2005 event is summarized in Table 4 assuming the mean specific asset values of residential areas (EUR 279 per $\mathrm{m}^{2}$ ) and the water depths of both simulation runs ("22a" and " $23 \mathrm{a}$ "). Out of the three commonly applied stage-damage functions only the loss function of ICPR (2001) lies within the $95 \%$ confidence interval of the reported loss, independent of the hydraulic-simulation run (Table 4, Fig. 5). While the results of MURL (2000) underestimate the observed flood loss in both runs clearly, the calculations based on Hydrotec (2002) overestimate the observed loss considerably (Table 4). For the simulation run "23a", for instance, the latter provides 4.6 times higher damage to buildings than reported. Even if the full range of the underlying asset values (i.e., the minimum (EUR 224 per $\mathrm{m}^{2}$ ) and maximum (EUR 353 per $\mathrm{m}^{2}$ ) values) is applied, none of these two functions is within the confidence interval in one of the two hydraulic-simulation runs. Some of these three standard functions were already used in different geographical regions before like in the German federal states of Saxony (Schwarz et al., 2005; Thieken et al., 2008) and Baden-Württemberg (Thieken et al., 2008; Apel et al., 2009; Merz and Thieken, 2009) but it has also been reported that these models tend to under- or overestimate observed damage to buildings (e.g., Schwarz et al., 2005; Thieken et al., 2008; Apel et al., 2009).

With regard to the newly derived loss models from the two subsets of Germany and Bavaria (including also the adapted multi-factorial model), the pattern is very different. Table 4 illustrates that none of the functions derived from the mixed data set from Germany is able to reproduce reliable loss estimates in the study area as far as only mean specific asset values are applied. Only when the full range of the specific asset values is taken into account, three functions (linear, linear (co.), square root (co.)) fall within the confidence interval when assuming the minimum specific asset value as a basis (data not shown). However, this is only valid for simulation run "22a", which is supposed to underestimate the flood extent in the area of Pflach (see Sect. 3.1). The best estimate based on the German-wide data set and the more plausible simulation run " $23 \mathrm{a}$ " is obtained by the linear function which considers also the effect of contamination in the study area. Even if the loss estimate for run " $23 \mathrm{a}$ " is outside of the confidence interval, the overestimation amounts only to a factor of 1.5 when the minimum specific asset value is applied (data not shown). In case of the adapted multi-factorial loss model FLEMO $_{\text {AT }}$ the overestimation is a little bit higher (factor 

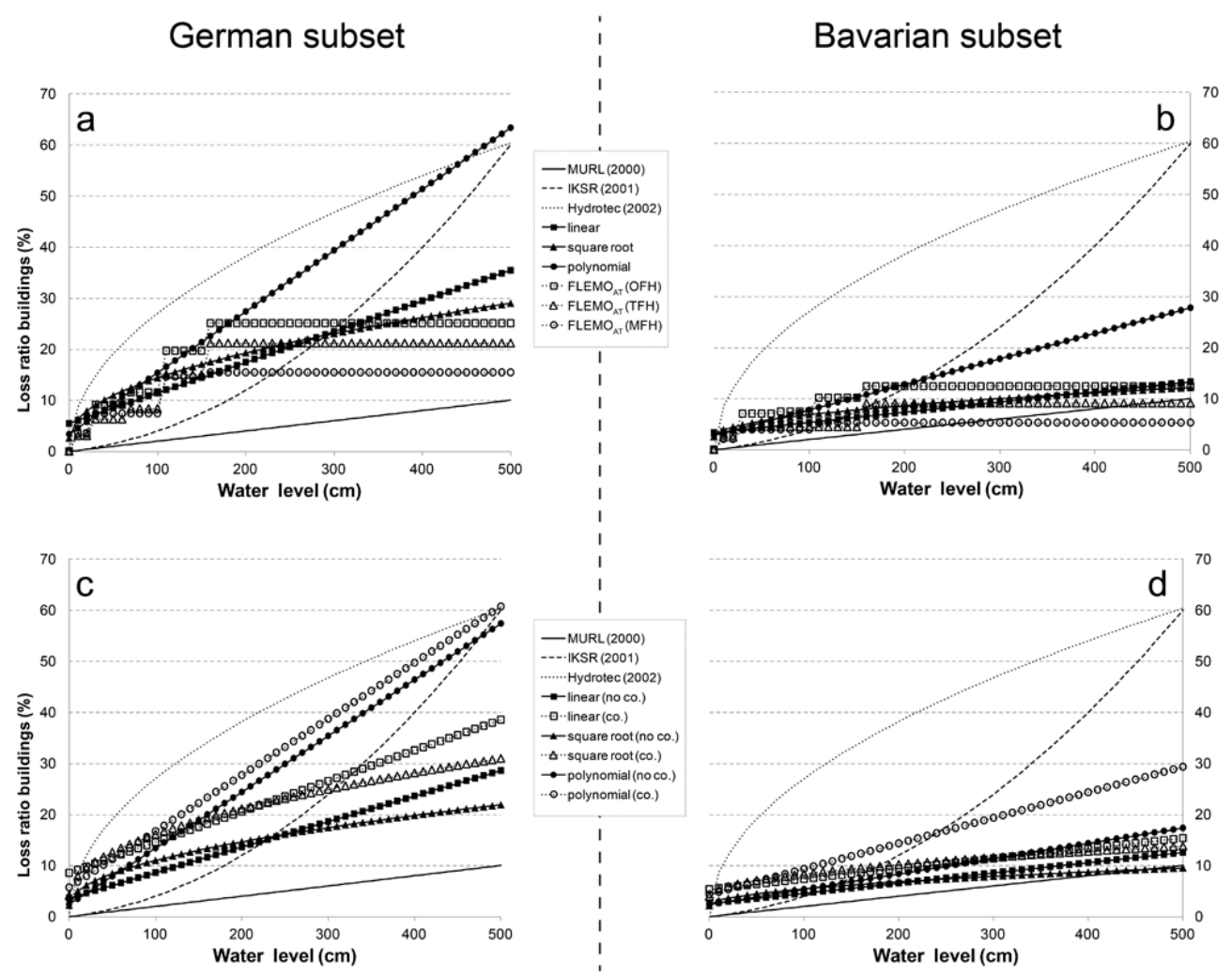

Fig. 4. Common stage-damage functions and newly derived ones from the mixed German subset left (a, c) and from the Bavarian subset right

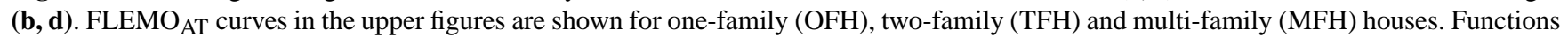
differentiating between contamination ("co.") and no contamination ("no co.") are shown in the lower figures (c, d) of the corresponding subset.

of 2). When contamination and the precautionary behavior are taken into account $\left(\mathrm{FLEMO}_{\mathrm{AT}+}\right)$, the estimates are even marginally better (overestimation factor of $\sim 1.7$ ) for this run and the lowest specific asset values.

From Table 4 it is further apparent that those loss functions which are derived from the Bavarian subset achieve clearly better results than those from the larger, but mixed German data set. Both for simulation run "22a" and for run " $23 \mathrm{a}$ " almost all derived functions estimate the reported loss well (i.e., the model estimates lie within the $95 \%$ interval) except for the polynomial function in case of run "23a" (Table 4, Fig 5). In fact, the latter is outside the confidence interval, but is only $\sim 1.4$ times higher than the reported loss and therefore more precise than the "best" function of the German-wide data set (linear function considering contamination and minimum asset values, see above) in this run. However, when the full range of the asset values are applied (Fig. 5), this function is also within this range when assuming the minimum asset values as input data. From Fig. 5 it can further be seen that three functions (linear, linear (co.), square root (co.)) are completely in the validation range independent of the applied asset values in the simulation run " $23 \mathrm{a}$ ". For the simulation run "22a" even the half of the derived functions (i.e., square root (co.), polynomial (co.) and both FLEMO models) lies within this confidence interval when the full range of the asset values is considered (Fig. 5). The most accurate functions

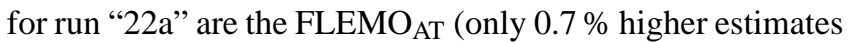
than the mean total loss in the amount of EUR $1.904 \mathrm{~m}$ ) and the linear functions (only $0.1 \%$ higher estimates than the median total loss in the amount of EUR $1.885 \mathrm{~m}$ ) when the mean and the maximum specific asset values are applied. In case of the more reliable simulation run "23a", the polynomial function which considers the effect of contamination and which is based on the minimum specific asset values achieves the best result by underestimating the reported loss by only $-1.1 \%$ (mean total damage) and $-0.1 \%$ (median total damage), respectively. Only slightly larger is the deviation of the FLEMO $_{\mathrm{AT}}$ model (also based on the minimum specific asset value), which overestimates the mean total damage by $1.2 \%$ and the median total damage by $2.2 \%$ in this simulation run.

The validation procedure strongly illustrates the importance of the site-specific evaluation of flood loss models. Using the reported structural flood loss on residential buildings as a quality criterion, it becomes apparent that general stage-damage curves for residential areas focusing on rather static flooding are hardly applicable in our mountainous test site with an interaction between static and dynamic flooding. Only the function of ICPR (2001) proved to be reliable at this 
Table 4. Comparison of different loss estimates with the observed flood damage ( $95 \%$ confidence interval) on residential buildings for the flood event of August 2005 ( $\checkmark$ and $\times$ means that estimate lies within or outside the confidence interval). Note: for all loss estimates only mean specific asset values are taken into account here.

\begin{tabular}{|c|c|c|c|c|c|}
\hline \multirow[b]{2}{*}{ Data set } & \multirow[b]{2}{*}{$\begin{array}{l}\text { Damage } \\
\text { function }\end{array}$} & \multicolumn{2}{|c|}{ Simulation run $22 \mathrm{a}$} & \multicolumn{2}{|c|}{ Simulation run $23 \mathrm{a}$} \\
\hline & & $\begin{array}{l}\text { Estimated losses } \\
\text { (in EUR m) }\end{array}$ & $\begin{array}{c}\text { Within } 95 \% \\
\text { interval }\end{array}$ & $\begin{array}{l}\text { Estimated losses } \\
\quad \text { (in EUR m) }\end{array}$ & $\begin{array}{c}\text { Within } 95 \% \\
\text { interval }\end{array}$ \\
\hline \multirow{3}{*}{ HOWAS } & MURL (2000) & 0.608 & $x$ & 0.842 & $x$ \\
\hline & ICPR (2001) & 1.736 & $\checkmark$ & 2.553 & $\checkmark$ \\
\hline & Hydrotec (2002) & 7.133 & $x$ & 9.094 & $x$ \\
\hline \multirow{8}{*}{ German subset } & linear & 3.114 & $x$ & 4.264 & $x$ \\
\hline & square root & 3.807 & $x$ & 4.776 & $x$ \\
\hline & polynomial & 4.509 & $x$ & 6.042 & $x$ \\
\hline & FLEMO $_{\mathrm{AT}}$ & 3.778 & $x$ & 4.887 & $x$ \\
\hline & linear (co.) & 2.903 & $x$ & 3.718 & $x$ \\
\hline & square root (co.) & 3.314 & $\times$ & 4.142 & $x$ \\
\hline & polynomial (co.) & 4.122 & $x$ & 5.506 & $x$ \\
\hline & FLEMO $_{A T+}$ & 3.342 & $\times$ & 4.322 & $\times$ \\
\hline \multirow{8}{*}{ Bavarian subset } & Linear & 1.560 & $\checkmark$ & 1.963 & $\checkmark$ \\
\hline & square root & 1.819 & $\checkmark$ & 2.244 & $\checkmark$ \\
\hline & polynomial & 2.181 & $\checkmark$ & 2.854 & $x$ \\
\hline & FLEMO $_{\mathrm{AT}}$ & 2.005 & $\checkmark$ & 2.510 & $\checkmark$ \\
\hline & linear (co.) & 1.471 & $\checkmark$ & 1.836 & $\checkmark$ \\
\hline & square root (co.) & 1.678 & $\checkmark$ & 2.060 & $\checkmark$ \\
\hline & polynomial (co.) & 1.898 & $\checkmark$ & 2.454 & $\checkmark$ \\
\hline & FLEMO $_{\mathrm{AT}+}$ & 1.872 & $\checkmark$ & 2.343 & $\checkmark$ \\
\hline \multicolumn{2}{|c|}{ Reported loss in 2005} & \multicolumn{2}{|c|}{ EUR 1.429 (2.5th percentile) } & \multicolumn{2}{|c|}{ EUR 2.662 (97.5th percentile) } \\
\hline
\end{tabular}

Note: functions with "co." in parentheses differentiate further between contamination and no contamination of the flood water, respectively.

site and can therefore be recommended for further loss estimations in this area even it was developed for the Rhine. The derivation of new stage-damage functions and the adaptation of the multi-factorial loss model shows that loss data where these models are based on and which are collected in a neighboring and also mountainous region with assumable similar building and flood event characteristics and further loss figures yields remarkably better results than (more) loss data from spatially different regions and dissimilar flood events with, for example, higher process intensities. This is in line with prior statements (e.g., Oliveri and Santoro, 2000; Kang et al., 2005; Luino et al., 2009) that loss functions should only be applied in related regions with similar depth-damage relationships particularly when water depth is the only factor considered. But even when other loss decisive parameters like contamination are additionally taken into account, no reliable loss estimates could be produced when the underlying loss data originate from various geographical regions like the German-wide data set. Also the application of a multifactorial model which was expected to produce more precise loss estimates failed as far as the basic data are not derived from a more similar and related region like Bavaria. Then, most of the employed loss models work well emphasizing the importance of the spatial aspect of the data basis.
Nevertheless, also the uncertainty of the underlying asset values has to be taken into account when loss estimates are evaluated (e.g., Egorova et al., 2008; de Moel and Aerts, 2011). In fact, most of the damage functions worked well with the mean specific asset values, but some of them achieved only good results with the full range (minimum and maximum specific values) of the site-specific asset values. Therefore, we recommend the usage of not only one (mean) property value as also this important component is associated with uncertainty (Egorova et al., 2008; de Moel and Aerts, 2011). In this context, it has also to be noticed that stage-damage curves which just miss the confidence interval should not generally be discarded as also the reported loss may be affected by uncertainties, even if we aggregated the observed damage to the whole study areas as recommended by Downton and Pielke (2005).

\subsection{Current flood risk estimates for residential areas}

In a last step, the current flood risk for residential areas was assessed for the seven investigated municipalities in the area of Reutte. Thereby four inundation scenarios were generated for the recurrence intervals $T=30,100,200$ and $300 \mathrm{yr}$ by considering the most recent structural protection measures 


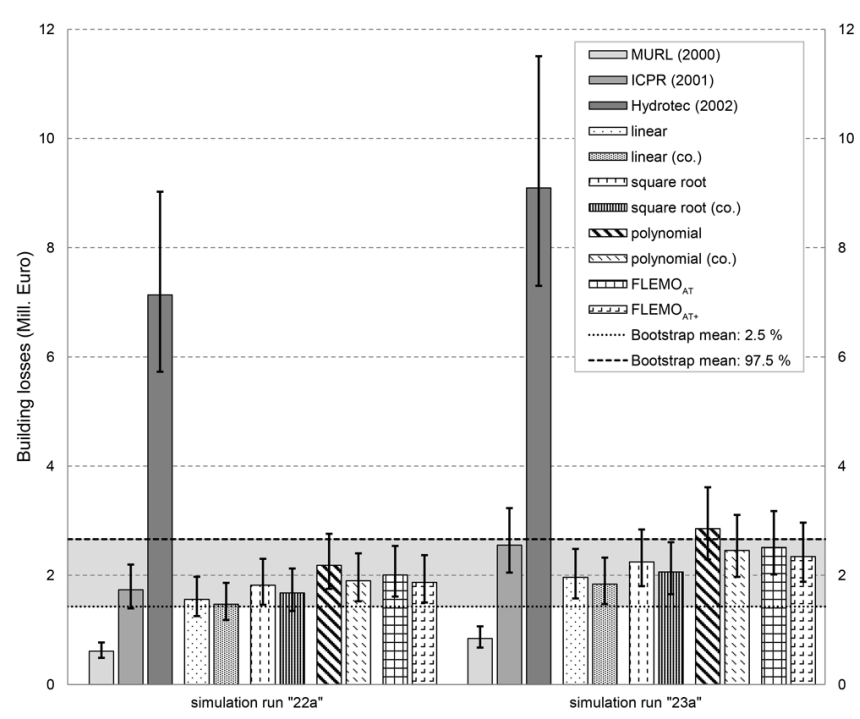

Fig. 5. Flood loss model estimations with error bars (due to the range of underlying asset values) for the flood event in August 2005 for the two hydraulic-simulation runs "22a" (dike heights as in 2005) and "23a" (dike heights as in 2005 but considering dike breaches) by means of the loss functions derived from the Bavarian subset. Loss estimates of the three standard functions (MURL, 2000; ICPR, 2001; Hydrotec, 2002) are also plotted here. The $95 \%$ confidence interval that was derived from reported losses by bootstrapping is highlighted in light grey.

erected in the aftermath of 2005 . However, these simulations do not comprise dike breach scenarios as it is assumed that the latest improvements of the levees in the municipality of Pflach, for example, allow no more failures in future. Thus the potential inundation areas are smaller (data not shown) leading to presumably lower potential damage on residential buildings for the $300 \mathrm{yr}$ flood in comparison to the flood of 2005.

To demonstrate the wide range of flood risk curves obtained from different damage functions and the intrinsic uncertainty of asset values all possible model combinations are shown in Fig. 6. Thereby each of the 19 damage functions (see Table 4) is combined with the full range of asset values (minimum, mean and maximum specific asset value) resulting in 57 specific model combinations. However, as shown before, a large part of the functions is not plausible for this study area. Particularly the common stage-damage curves (except the function of ICPR, 2001) and the majority of the functions derived from the mixed German-wide data set are hardly applicable, independent of the underlying asset value and simulation run. In sum, 28 non-plausible model combinations can therefore be discarded contributing to a large uncertainty in the flood risk estimates (Fig. 6). For the $300 \mathrm{yr}$ flood, for example, the range differs by EUR $5.9 \mathrm{~m}$, which corresponds to a factor of $\sim 18$ between the highest and the lowest estimate. In contrast, the uncertainty is considerably reduced when only plausible model combinations,

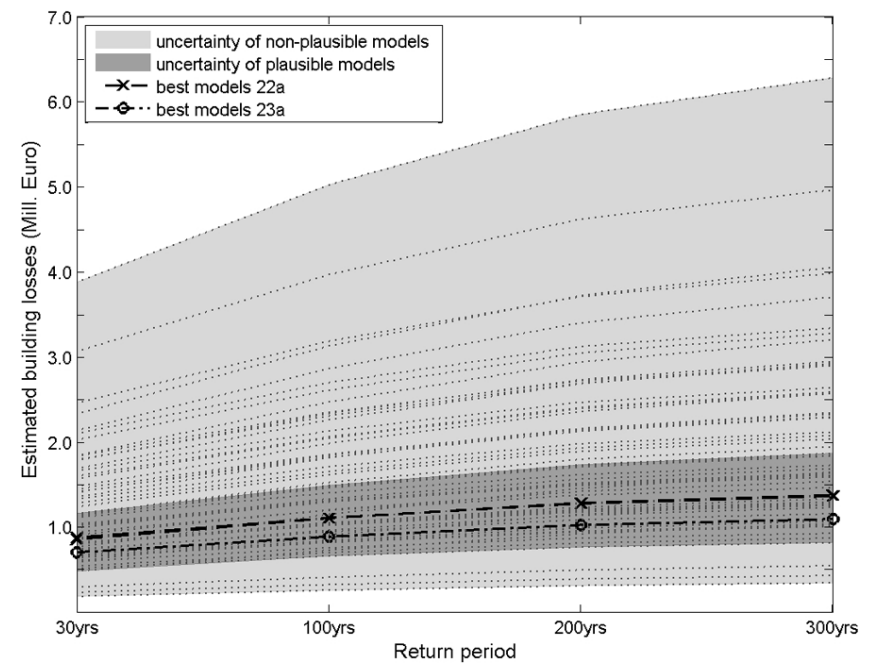

Fig. 6. Current risk curve for residential areas with associated uncertainty bounds based on the range of 29 plausible model combinations (i.e., successfully validated models), and based on the range of 28 additional, non-plausible loss model combinations. The most accurate functions (i.e., the smallest deviation to the observed loss) in case of the hydraulic-simulation runs " $22 \mathrm{a}$ " and "23a" for 2005 are shown in dotted lines.

which were successfully validated for the 2005 event in the study area, are employed. A majority of these models is derived from the Bavarian subset where the simulated loss lies within the confidence interval (Fig. 5) except for the polynomial function when the maximum asset value is applied. The range of these remaining 29 model combinations is then reduced to only EUR $1.0 \mathrm{~m}$ corresponding to a factor of 2.3 between the estimates of the highest and the lowest plausible models for this return period.

The best estimated risk curves are also shown in Fig. 6, derived from the most accurate model combinations of the two hydraulic-simulation runs (i.e., FLEMO $_{\mathrm{AT}}$ and the linear function for run " $22 \mathrm{a}$ " and the polynomial function considering contamination for run " $23 \mathrm{a}$ "). The maximum range of these specific combinations is only EUR $0.3 \mathrm{~m}$ (factor of 1.3) and illustrates the remaining deviation between the most accurate models as far as two hydraulic-simulation runs are applied for the flood loss model validation. However, for a complete assessment of the associated uncertainty for flood risk curves also the uncertainty of the flood frequency estimates has to be taken into account (e.g., Merz and Thieken, 2009).

Nevertheless, the focus of this study was not to evaluate the uncertainty of flood risk curves, but to demonstrate how large only the absolute contribution within risk estimates might be when loss models are not validated before in the region under study. Thereby the significant range of different damage functions and diverging asset values became apparent when flood risk curves are calculated. Similar findings were also observed by de Moel and Aerts (2011), for 
instance, when different flood loss models and asset values are applied in frame of flood risk estimations. However, de Moel and Aerts (2011) did not show to which extent this range could be reduced by proper model validation before as their focus aimed on the relative comparison of different uncertainty sources like land use data, etc. in frame of flood risk analysis. Furthermore, the effect of different loss models in their study is distorted due to the different underlying asset values of each model. We used instead identical asset, sitespecific asset values (but also accounting for intrinsic uncertainty) for all relative damage functions to isolate the single effect of model choice. Future research should consequently be aware of the associated uncertainty in case of loss estimations which cannot be validated in the corresponding study areas due to the lack of real damage data. In case that no real loss data are available for the flood loss model evaluation, loss functions should at least be selected or derived from related regions with similar building and flood event characteristics.

\section{Conclusions}

Depth-damage functions are the international standard to assess direct flood losses in urban areas. Besides the simplicity of stage-damage functions neglecting other important damage influencing parameters, such functions are often used in different geographical regions without evaluating their performance, mostly due to the lack of real damage data from the study area. This study aimed therefore at investigating the applicability and transferability of different flood loss functions to other geographical regions.

The data basis from which the empirical loss models were derived was split in two subsets with all loss data from different regions in Germany, on the one hand. The second subset, on the other hand, comprises only loss data which were collected in a more related region, such as the federal state of Bavaria, Germany, which is very close to the Austrian study area. In addition, three common stage-damage functions were used derived from a large but different German flood loss database and applied in previous studies for lowland rivers before. In accordance with the hypothesis that more similar and related regions (in the sense of more similar building and flood event characteristics) might have quite identical relationships between flood losses and impact parameters this study clearly showed that those loss functions performed significantly better than those which are derived from a very heterogeneous sample of more dissimilar regions and different flood events. Although the wellperforming functions are also connected with marginal uncertainties, their range could be reduced remarkably in contrast to the functions from the German-wide data set or even from another flood loss database with more but mixed loss reports (i.e., the standard functions). The substantial deviations of the applied functions demonstrate (1) the need to de- rive functions from more similar regions that better reflect the characteristics of the region under study and (2) the importance to include more factors than only water level explaining flood damage. We suppose that apart from similar building characteristics also the flood characteristics/processes of the single events play an important role for the flood loss relationship. Since the mean flood losses on buildings in Saxony were considerably higher it is expected that also the extreme event character of the flood (in the year 2002) lead to different damage figures, apart from differences in the building characteristics. Future works should therefore also investigate the potential variability of flood losses due to different process characteristics of the single flood events.

All in all, the importance of the uncertainty caused by different loss functions and based on loss data of different geographical regions becomes apparent when a flood risk analysis was carried out. There, the estimates of the non-plausible model combinations (i.e., unsuccessfully validated models by means of the flood event in 2005) differ by a factor of 18 between the highest and lowest loss calculation in case of a $300 \mathrm{yr}$ flood. In contrast, the uncertainty range of the successfully validated model combinations is reduced to a factor of 2.3 for this return period. Even if the risk was only estimated for residential areas it should become more evident how large uncertainties of single methodological steps like the damage modeling within risk analysis might be. Previous studies already indicated that the largest impact on damage estimation is caused by the shape of the applied depth-damage curve as well as the associated asset values, while the accuracy of the hydraulic input is of minor importance. The validation procedure performed in this study underlined, however, to which extent this uncertainty can be reduced in case of flood risk analysis.

Due to these findings, we encourage future research not only to be aware of the problematic applicability and transferability of flood loss models in different geographical regions. Instead, more systematic flood loss data collection is needed to adapt and validate flood loss models in other study areas since they are often used in risk analysis, regardless of their associated uncertainties. In case of missing data for model calibration and validation, loss models should at least be selected from related and more similar regions to improve the reliability of such estimates.

Acknowledgements. The authors thank the "Klima- und Energiefonds" funding a large part of this study carried out in frame of the FloodTimeS project of the Austrian Climate Research Program (contract no. A963631). Furthermore, the first author thanks the University of Innsbruck for the scholarship "Doktoratsstipendiums NEU aus der Nachwuchsförderung der LFU Innsbruck". For the provision of the spatial data and data from the disaster funds the Tyrolean government is gratefully acknowledged. Lastly, we appreciate the expert advice of Friedrich Schöberl, University of Innsbruck, for the hydraulic modeling. 
The service charges for this open access publication have been covered by the University of Innsbruck and the "Tiroler Wissenschaftsfonds" (TWF).

Edited by: P. Bubeck

Reviewed by: B. Jongman, V. Meyer, and one anonymous referee

\section{References}

Amt der NÖ Landesregierung: Standardisiertes Bewertungsverfahren für Hochwasserschäden bei Wohngebäuden und zugehörigen Nebengebäuden einschliesslich Zentralheizung, Inventar und Aussenanlagen. Richtwerte 2012/13, St.Pölten, available at: http://www.noe.gv.at/bilder/d63/Katastrophenschaeden_ Technikerbehelf_2012.pdf?25222 (last access: May 2013), Amt der NÖ Landesregierung - Gruppe Baudirektion, St. Pölten, 2012.

Amt der Tiroler Landesregierung: Hydrologische Übersicht August 2005, Landesbaudirektion - Hydrographie, Innsbruck, 2005.

Amt der Tiroler Landesregierung: Rechnungsabschluss 2005 des Landes Tirol, Landesrechnungshof, Innsbruck, 2006.

Amt der Tiroler Landesregierung: Regionalwirtschaftliches Programm für die Region Naturschutzgebiet-Naturpark Tiroler Lech, Abteilung Raumordnung - Statistik, Innsbruck, 2008.

Apel, H., Aronica, G., Kreibich, H., and Thieken, A.: Flood risk analyses - how detailed do we need to be?, Nat. Hazards, 49, 79-98, doi:10.1007/s11069-008-9277-8, 2009.

BMLFUW: Hochwasser 2005 - Ereignisdokumentation der Bundeswasserbauverwaltung, des Forsttechnischen Dienstes für Wildbach- und Lawinenverbauung und des Hydrographischen Dienstes, Bundesministerium für Land- und Forstwirtschaft, Umwelt- und Wasserwirtschaft - Sektion Wasser, Vienna, 2006.

Bubeck, P., de Moel, H., Bouwer, L. M., and Aerts, J. C. J. H.: How reliable are projections of future flood damage?, Nat. Hazards Earth Syst. Sci., 11, 3293-3306, doi:10.5194/nhess-11-32932011, 2011.

Büchele, B., Kreibich, H., Kron, A., Thieken, A., Ihringer, J., Oberle, P., Merz, B., and Nestmann, F.: Flood-risk mapping: contributions towards an enhanced assessment of extreme events and associated risks, Nat. Hazards Earth Syst. Sci., 6, 485-503, doi:10.5194/nhess-6-485-2006, 2006.

BWW, BRP, BUWAL: Berücksichtigung der Hochwassergefahren bei raumwirksamen Tätigkeiten, Bundesamt für Wasserwirtschaft, Bundesamt für Raumplanung, Bundesamt für Umwelt, Wald und Landschaft, Bern und Biel, 1997.

Cammerer, H. and Thieken, A. H.: Flood Loss Reduction due to Private Precaution, in: Urban Flood Risk Management - Approaches to enhance resilience of communities, Proceedings of the International Symposium UFRIM, Graz, Austria, 21-23 September 2011, 381-386, 2011.

Cammerer, H. and Thieken, A.: Historical development and future outlook of the flood damage potential of residential areas in the Alpine Lech Valley (Austria) between 1971 and 2030, Regional Environ. Change, 13, 999-1012, doi:10.1007/s10113-013-04079, 2013.

Cammerer, H., Thieken, A., and Verburg, P.: Spatio-temporal dynamics in the flood exposure due to land use changes in the Alpine Lech Valley in Tyrol (Austria), Nat. Hazards, 68, 12431270, doi:10.1007/s11069-012-0280-8, 2013.
Chang, L.-F., Lin, C.-H., and Su, M.-D.: Application of geographic weighted regression to establish flood-damage functions reflecting spatial variation, Water SA, 34, 209-215, 2008.

Cochrane, H.: Economic loss: myth and measurement, Disaster Prevent. Manage., 13, 290-296, doi:10.1108/09653560410556500, 2004.

de Moel, H. and Aerts, J.: Effect of uncertainty in land use, damage models and inundation depth on flood damage estimates, Nat. Hazards, 58, 407-425, doi:10.1007/s11069-010-9675-6, 2011.

de Moel, H., van Alphen, J., and Aerts, J. C. J. H.: Flood maps in Europe - methods, availability and use, Nat. Hazards Earth Syst. Sci., 9, 289-301, doi:10.5194/nhess-9-289-2009, 2009.

de Moel, H., Asselman, N. E. M., and Aerts, J. C. J. H.: Uncertainty and sensitivity analysis of coastal flood damage estimates in the west of the Netherlands, Nat. Hazards Earth Syst. Sci., 12, 10451058, doi:10.5194/nhess-12-1045-2012, 2012.

Dobler, C., Stötter, J., and Schöberl, F.: Assessment of climate change impacts on the hydrology of the Lech Valley in northern Alps, J. Water Climate Change, 1, 207-218, doi:10.2166/wcc.2010.122, 2010.

Downton, M. and Pielke, R.: How Accurate are Disaster Loss Data? The Case of U.S. Flood Damage, Nat. Hazards, 35, 211-228, doi:10.1007/s11069-004-4808-4, 2005.

Dung, N. V., Merz, B., Bárdossy, A., Thang, T. D., and Apel, H.: Multi-objective automatic calibration of hydrodynamic models utilizing inundation maps and gauge data, Hydrol. Earth Syst. Sci., 15, 1339-1354, doi:10.5194/hess-15-1339-2011, 2011.

Dutta, D., Herath, S., and Musiake, K.: A mathematical model for flood loss estimation, J. Hydrol., 277, 24-49, doi:10.1016/S0022-1694(03)00084-2, 2003.

Ebner, V., Fritzmann, P., Gstaiger, V., Kelterer, M., Maurer, D., and Nieland, S.: Rekonstruktion der Hochwasseranschlagslinien an Gebäuden vom Augusthochwasser 2005 und Vergleich der Ergebnisse mit den HORA-Modellierungen, Abschlussbericht Projektmodul 2006/07, Institut für Geographie, Innsbruck, 2007.

EC (European Commission): A new EU Floods Directive 2007/60/EC, available at: http://ec.europa.eu/environment/water/ flood_risk/ (last access: May 2013), 2007.

Egorova, R., van Noortwijk, J. M., and Holterman, S. R.: Uncertainty in flood damage estimation, Int. J. River Basin Manage., 6, 139-148, doi:10.1080/15715124.2008.9635343, 2008.

Elmer, F., Thieken, A. H., Pech, I., and Kreibich, H.: Influence of flood frequency on residential building losses, Nat. Hazards Earth Syst. Sci., 10, 2145-2159, doi:10.5194/nhess-10-21452010, 2010.

Freni, G., La Loggia, G., and Notaro, V.: Uncertainty in urban flood damage assessment due to urban drainage modelling and depthdamage curve estimation, Water Sci. Technol., 61, 2979-2993, 2010.

Fuchs, S., Heiss, K., and Hübl, J.: Towards an empirical vulnerability function for use in debris flow risk assessment, Nat. Hazards Earth Syst. Sci., 7, 495-506, doi:10.5194/nhess-7-4952007, 2007.

Habersack, H., Bügel, J., and Petrascheck, A.: Analyse der Hochwasserereignisse vom August 2002 - FloodRisk, Synthesebericht, Bundesministerium für Land- und Forstwirtschaft, Umwelt und Wasserwirtschaft, Wien, 2004.

Holub, M. and Fuchs, S.: Mitigating mountain hazards in Austria - legislation, risk transfer, and awareness building, Nat. 
Hazards Earth Syst. Sci., 9, 523-537, doi:10.5194/nhess-9-5232009, 2009.

Holub, M., Suda, J., and Fuchs, S.: Mountain hazards: reducing vulnerability by adapted building design, Environ. Earth Sci., 66, 1853-1870, doi:10.1007/s12665-011-1410-4, 2012.

Huttenlau, M. and Stötter, J.: Ermittlung des monetären Werteinventars als Basis von Analysen naturgefahreninduzierter Risiken in Tirol (Österreich), Geogr. Helv., 63, 85-93, doi:10.5194/gh63-85-2008, 2008.

Hydrotec: Hochwasser-Aktionsplan Lippe, Grundlagen, Überflutungsgebiet, Schadenspotenzial, Defizite und Maßnahmen, Studie im Auftrag des Staatlichen Umweltamts Lippstadt, Aachen, 2002.

ICPR (International Commission for the Protection the Rhine): Atlas of Flood Danger and Potential Damage Due to Extreme Floods of the Rhine, International Commission for the Protection of the Rhine, Koblenz, 2001.

Jongman, B., Kreibich, H., Apel, H., Barredo, J. I., Bates, P. D., Feyen, L., Gericke, A., Neal, J., Aerts, J. C. J. H., and Ward, P. J.: Comparative flood damage model assessment: towards a European approach, Nat. Hazards Earth Syst. Sci., 12, 3733-3752, doi:10.5194/nhess-12-3733-2012, 2012.

Kang, J.-L., Su, M.-D., and Chang, L.-F.: Loss functions and framework for regional flood damage estimation in residential area, J. Mar. Sci. Technol., 13, 193-199, 2005.

Keiler, M., Zischg, A., and Fuchs, S.: Methoden zur GIS-basierten Erhebung des Schadenpotenzials für naturgefahreninduzierte Risiken, in: GIS und Sicherheitsmanagement, edited by: Strobl, J. and Roth, C., Wichmann, Heidelberg, 118-128, 2006.

Kelman, I. and Spence, R.: An overview of flood actions on buildings, Eng. Geol., 73, 297-309, doi:10.1016/j.enggeo.2004.01.010, 2004.

Kreibich, H. and Thieken, A. H.: Assessment of damage caused by high groundwater inundation, Water Resour. Res., 44, W09409, doi:10.1029/2007wr006621, 2008.

Kreibich, H. and Thieken, A. H.: Coping with floods in the city of Dresden, Germany, Nat. Hazards, 51, 423-436, doi:10.1007/s11069-007-9200-8, 2009.

Kreibich, H., Thieken, A. H., Petrow, T., Müller, M., and Merz, B.: Flood loss reduction of private households due to building precautionary measures - lessons learned from the Elbe flood in August 2002, Nat. Hazards Earth Syst. Sci., 5, 117-126, doi:10.5194/nhess-5-117-2005, 2005.

Kreibich, H., Piroth, K., Seifert, I., Maiwald, H., Kunert, U., Schwarz, J., Merz, B., and Thieken, A. H.: Is flow velocity a significant parameter in flood damage modelling?, Nat. Hazards Earth Syst. Sci., 9, 1679-1692, doi:10.5194/nhess-9-1679-2009, 2009.

Kreibich, H., Christenberger, S., and Schwarze, R.: Economic motivation of households to undertake private precautionary measures against floods, Nat. Hazards Earth Syst. Sci., 11, 309-321, doi:10.5194/nhess-11-309-2011, 2011a.

Kreibich, H., Meyer, S., and Diekkrüger, B.: Weiterentwicklung von FLEMOps zur Modellierung von Grundhochwasserschäden und Wohngebäuden, Hydrol. Wasserbewirts., 55, 300-309, 2011 b.

Kröll, A.: Chronik der Gemeinde Pflach, Museumsvereins des Bezirkes Reutte, Reutte, 607 pp., 2007.

Luino, F., Cirio, C., Biddoccu, M., Agangi, A., Giulietto, W., Godone, F., and Nigrelli, G.: Application of a model to the evaluation of flood damage, GeoInformatica, 13, 339-353, doi:10.1007/s10707-008-0070-3, 2009.

Merz, B. and Thieken, A.: Flood risk curves and uncertainty bounds, Nat. Hazards, 51, 437-458, doi:10.1007/s11069-0099452-6, 2009.

Merz, B., Kreibich, H., Thieken, A., and Schmidtke, R.: Estimation uncertainty of direct monetary flood damage to buildings, Nat. Hazards Earth Syst. Sci., 4, 153-163, doi:10.5194/nhess-4-1532004, 2004.

Merz, B., Kreibich, H., Schwarze, R., and Thieken, A.: Review article "Assessment of economic flood damage", Nat. Hazards Earth Syst. Sci., 10, 1697-1724, doi:10.5194/nhess-10-16972010, 2010.

Merz, B., Kreibich, H., and Lall, U.: Multi-variate flood damage assessment: a tree-based data-mining approach, Nat. Hazards Earth Syst. Sci., 13, 53-64, doi:10.5194/nhess-13-53-2013, 2013.

Meyer, V., Becker, N., Markantonis, V., Schwarze, R., van den Bergh, J. C. J. M., Bouwer, L. M., Bubeck, P., Ciavola, P., Genovese, E., Green, C., Hallegatte, S., Kreibich, H., Lequeux, Q., Logar, I., Papyrakis, E., Pfurtscheller, C., Poussin, J., Przyluski, V., Thieken, A. H., and Viavattene, C.: Review article: Assessing the costs of natural hazards - state of the art and knowledge gaps, Nat. Hazards Earth Syst. Sci., 13, 1351-1373, doi:10.5194/nhess-13-1351-2013, 2013.

Mudelsee, M., Börngen, M., Tetzlaff, G., and Grünewald, U.: Extreme floods in central Europe over the past 500 years: Role of cyclone pathway “Zugstrasse Vb”, J. Geophys. Res. Atmos., 109, D23101, doi:10.1029/2004jd005034, 2004.

MURL: Potenzielle Hochwasserschäden am Rhein in NordrheinWestfalen, Ministerium für Umwelt, Raumordnung und Landwirtschaft des Landes Nordrhein-Westfalen, Düsseldorf, 2000.

Nicholas, J., Holt, G. D., and Proverbs, D.: Towards standardising the assessment of flood damaged properties in the UK, Struct. Survey, 19, 163-172, 2001.

Noack, M. and Yörük, A.: Uncertainty in hydrodynamic-numerical modelling of flood areas, Hydrol. Wasserbewirts., 52, 73-178, 2008.

Nujic, M.: HYDRO_AS-2D - Ein zweidimensionales Strömungsmodell für die wasserwirtschaftliche Praxis, Benutzerhandbuch, Rosenheim, 2003.

Oliveri, E. and Santoro, M.: Estimation of urban structural flood damages: the case study of Palermo, Urban Water J., 2, 223-234, doi:10.1016/s1462-0758(00)00062-5, 2000.

Papathoma-Köhle, M., Kappes, M., Keiler, M., and Glade, T.: Physical vulnerability assessment for alpine hazards: state of the art and future needs, Nat. Hazards, 58, 645-680, doi:10.1007/s11069-010-9632-4, 2011.

Penning-Rowsell, E. C. and Chatterton, J. B.: The benefits of flood alleviation: A manual of assessment techniques, Gower Technical Press, Aldershot, 1977.

Penning-Rowsell, E., Johnson, C., Tunstall, S., Tapseel, S., Morris, J., Chatterton, J., and Green, C.: The Benefits of Flood and Coastal Risk Management: a Handbook of Assessment Techniques, Middlesex University Press, London, 2005.

Pistrika, A. and Jonkman, S.: Damage to residential buildings due to flooding of New Orleans after hurricane Katrina, Nat. Hazards, 54, 413-434, doi:10.1007/s11069-009-9476-y, 2010.

Prettenthaler, F., Amrusch, P., and Habsburg-Lothringen, C.: Estimation of an absolute flood damage curve based on an Austrian 
case study under a dam breach scenario, Nat. Hazards Earth Syst. Sci., 10, 881-894, doi:10.5194/nhess-10-881-2010, 2010.

Raschky, P., Schwarze, R., Schwindt, M., and Weck-Hannemann, H.: Alternative Finanzierungs- und Versicherungslösungen. Vergleich unterschiedlicher Risikotransfersysteme dreier vom Augusthochwasser 2005 betroffener Länder: Deutschland, Österreich und Schweiz, Präventionsstiftung der Kantonalen Gebäudeversicherungen, Bern, 2009.

Schwarz, J. and Maiwald, H.: Prognose der Bauwerksschädigung unter Hochwassereinwirkung, Bautechnik, 84, 450-464, doi:10.1002/bate.200710039, 2007.

Schwarz, J., Maiwald, H., and Gerstberger, A.: Quantifizierung der Schäden infolge Hochwassereinwirkung: Fallstudie Eilenburg, Bautechnik, 82, 845-856, doi:10.1002/bate.200590247, 2005.

Seibert, P., Frank, A., and Formayer, H.: Synoptic and regional patterns of heavy precipitation in Austria, Theor. Appl. Climatol., 87, 139-153, doi:10.1007/s00704-006-0198-8, 2007.

Seifert, I., Kreibich, H., Merz, B., and Thieken, A. H.: Application and validation of FLEMOcs - a flood-loss estimation model for the commercial sector, Hydrolog. Sci. J., 55, 1315-1324, doi:10.1080/02626667.2010.536440, 2010.

Smith, D. I.: Flood damage estimation - a review of urban stagedamage curves and loss functions, Water SA, 20, 231-238, 1994.

Smith, K. and Ward, R.: Floods: Physical processes and Human Impacts, John Wiley \& Sons, Chichester, 1998.

Statistics Austria: Baukostenindex Wohnhaus- und Siedlungsbau Basisjahr 2005, available at: http://www.statistik.at/web_de/ statistiken/preise/baukostenindex/index.html (last access: May 2013), 2013a.

Statistics Austria: Ein Blick auf die Gemeinden, available at: http://www.statistik.at/web_de/services/ein_blick_auf_die_ gemeinde/index.html (last access: May 2013), 2013b.

Thieken, A. H., Müller, M., Kreibich, H., and Merz, B.: Flood damage and influencing factors: new insights from the $\mathrm{Au}-$ gust 2002 flood in Germany, Water Resour. Res., 41, W12430, doi:10.1029/2005wr004177, 2005.

Thieken, A. H., Müller, M., Kleist, L., Seifert, I., Borst, D., and Werner, U.: Regionalisation of asset values for risk analyses, Nat. Hazards Earth Syst. Sci., 6, 167-178, doi:10.5194/nhess-6-1672006, 2006.
Thieken, A. H., Kreibich, H., Müller, M., and Merz, B.: Coping with floods: preparedness, response and recovery of flood-affected residents in Germany in 2002, Hydrol. Sci. J., 52, 1016-1037, doi:10.1623/hysj.52.5.1016, 2007.

Thieken, A., Olschewski, A., Kreibich, H., Kobsch, S., and Merz, B.: Development and evaluation of FLEMOps - a new Flood Loss Estimation MOdel for the private sector, in: Flood Recovery, Innovation and Response, edited by: Proverbs, D., Brebbia, C. A., and Penning-Rowsell, E., WIT Press, 315-324, 2008.

Thieken, A. H., Seifert, I., and Merz, B.: Hochwasserschäden: Erfassung, Abschätzung und Vermeidung, Oekom Verlag $\mathrm{GmbH}$, München, 2010.

Thieken, A. H., Cammerer, H., Dobler, C., Lammel, J., Bronstert, A., Stötter, J., and Schöberl, F.: Analysing changes in flood risks in an Alpine catchment, in: Managing Alpine Future II - Inspire and Drive Sustainable Mountain Regions, Proceedings of the Innsbruck Conference 23-23 November 2011, 97-107, 2011.

Thywissen, K.: Components of Risk. A Comparative Glossary, United Nation University, 2006.

Totschnig, R. and Fuchs, S.: Mountain torrents: Quantifying vulnerability and assessing uncertainties, Eng. Geol., 155, 31-44, doi:10.1016/j.enggeo.2012.12.019, 2013.

Totschnig, R., Sedlacek, W., and Fuchs, S.: A quantitative vulnerability function for fluvial sediment transport, Nat. Hazards, 58, 681-703, doi:10.1007/s11069-010-9623-5, 2011.

van Bebber, W. J.: Die Wettervorhersage, 2nd Edn., Enke, Stuttgart, 219 pp., 1898.

van der Veen, A. and Logtmeijer, C.: Economic Hotspots: Visualizing Vulnerability to Flooding, Nat Hazards, 36, 65-80, doi:10.1007/s11069-004-4542-y, 2005.

White, G.: Human adjustment to floods - a Geographical Approach to the Flood Problem in the United States, Research Paper No. 29, University of Chicago, USA, 1945.

Wuensch, A., Herrmann, U., Kreibich, H., and Thieken, A. H.: The role of disaggregation of asset values in flood loss estimation: a comparison of different modeling approaches at the Mulde River, Germany, Environ. Manage., 44, 524-541, doi:10.1007/s00267009-9335-3, 2009. 